San Jose State University

SJSU ScholarWorks

Master's Theses

Master's Theses and Graduate Research

Spring 2014

\title{
Structure and Emplacement of Cretaceous Plutons in Northwest Yosemite National Park, California
}

Ashley Van Dyne

San Jose State University

Follow this and additional works at: https://scholarworks.sjsu.edu/etd_theses

\section{Recommended Citation}

Van Dyne, Ashley, "Structure and Emplacement of Cretaceous Plutons in Northwest Yosemite National Park, California" (2014). Master's Theses. 4442.

DOI: https://doi.org/10.31979/etd.akfj-5ha8

https://scholarworks.sjsu.edu/etd_theses/4442

This Thesis is brought to you for free and open access by the Master's Theses and Graduate Research at SJSU ScholarWorks. It has been accepted for inclusion in Master's Theses by an authorized administrator of SJSU ScholarWorks. For more information, please contact scholarworks@sjsu.edu. 


\title{
STRUCTURE AND EMPLACEMENT OF CRETACEOUS PLUTONS, NORTHWEST
} YOSEMITE NATIONAL PARK, CALIFORNIA

\author{
A Thesis \\ Presented to \\ The Faculty of the Department of Geology \\ San José State University \\ In partial Fulfillment \\ of the Requirements for the Degree \\ Master of Science
}

by

Ashley L. Van Dyne

May 2014 
(C) 2014

Ashley L. Van Dyne

ALL RIGHTS RESERVED 
The Designated Thesis Committee Approves the Thesis Titled

\section{STRUCTURE AND EMPLACEMENT OF CRETACEOUS PLUTONS, NORTHWEST YOSEMITE NATIONAL PARK, CALIFORNIA}

by

Ashley L. Van Dyne

\section{APPROVED FOR THE DEPARTMENT OF GEOLOGY \\ SAN JOSE STATE UNIVERSITY}

April 2014

Dr. Robert Miller

Dr. Jonathan Miller

Dr. Ellen Metzger
Department of Geology

Department of Geology

Department of Geology 


\begin{abstract}
STRUCTURE AND EMPLACEMENT OF CRETACEOUS PLUTONS, NORTHWEST YOSEMITE NATIONAL PARK, CALIFORNIA

by Ashley L. Van Dyne
\end{abstract}

The 103-98 Ma Yosemite Valley Intrusive Suite, younger Granodiorite North of Tuolumne Peak, and 97 Ma Yosemite Creek Granodiorite intrude plutonic and metasedimentary host rocks of the central Sierra Nevada batholith. Precambrian to Cambrian metasedimentary rocks separate the Yosemite Valley Intrusive Suite from the younger (94-85 Ma) Tuolumne Intrusive Suite, and are interpreted to represent the original extent of the older suite. The Mt. Hoffman granodiorite and Taft Granite of the Yosemite Valley Intrusive Suite record evidence for the development of magma chambers, whereas the Tuolumne Peak and Yosemite Creek granodiorites were likely constructed via several small increments, and a sizable magma chamber did not form. Accommodation of magma was probably facilitated by a combination of processes, but there is only direct evidence for minor stoping. The dominant northwest-striking magmatic foliation in the Mt. Hoffman granodiorite records regional northeast-southwest shortening strain. Variations in strike of magmatic foliation in the Taft Granite likely results from a combination of regional strain and internal processes within a magma chamber. 


\section{ACKNOWLEDGEMENTS}

Completion of this thesis would not have been possible without the assistance, mentoring, and support that came in many forms and from many people in my life. First, I would like to thank my family who have always provided me with a foundation of love and strength, without which the possibility of this thesis, this undertaking, never would have appeared possible. Thank you for your support and encouragement throughout this process. Thank you to my field assistants, Kelly Dustin, Susan Gervais, Robert Schoch, and Bret Treece. Your assistance, enthusiasm, and insights were invaluable and made even the most arduous of days in my field area enjoyable and fruitful. I would also like to thank the National Park Service for facilitating and supporting my research in Yosemite National Park and the United States Geological Survey for the funding (EDMAP Grant) that made this research possible. I would like to extend a very sincere thank you to my thesis committee, Jonathan Miller and Ellen Metzger, for your guidance and assistance throughout this process. Your suggestions and edits were enormously helpful in the development of my understanding and in the final preparation of this thesis. Finally, I would like to express my deepest gratitude to my advisor, Robert Miller, whose role in completion of this thesis cannot be overstated. Thank you for the days you spent in my field area, your guidance through many discussions, the countless edits, and unwavering support throughout this very long, but wonderful process. I feel very fortunate to have benefited so much from your knowledge and am truly in awe of your dedication to your students. Thank you. 


\section{TABLE OF CONTENTS}

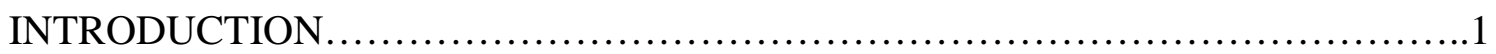

Geologic Setting..............................................................

Previous Work...................................................................

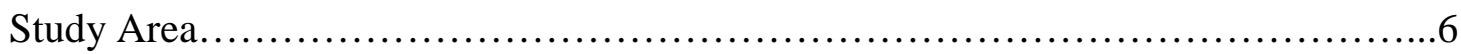

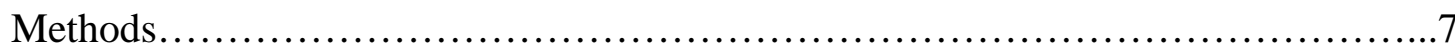

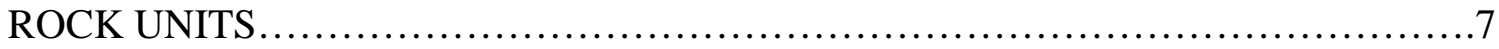

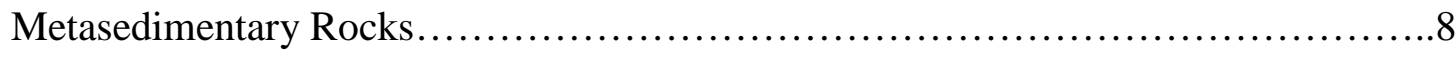

Yosemite Valley Intrusive Suite...............................................12

Mt. Hoffman Granodiorite and Associated Mafic Bodies........................13

Double Rock Granodiorite..................................................18

Taft Granite............................................................. 18

Tuolumne Peak Granodiorite....................................................25

Yosemite Creek Granodiorite.................................................27

Medium-grained Yosemite Creek Granodiorite................................29

Porphyritic Yosemite Creek Granodiorite.....................................29

Tonalitic Yosemite Creek Unit...................................................

Glen Aulin Tonalite...........................................................33

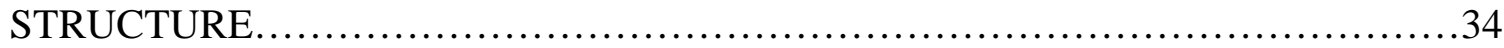

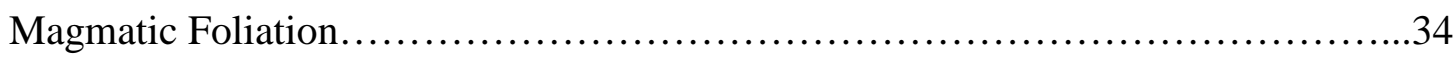

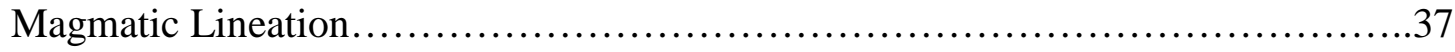

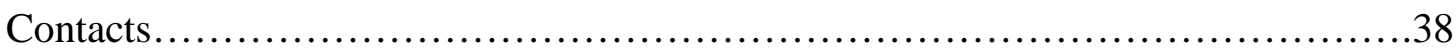


Metasedimentary Rock Contacts...........................................38

Yosemite Valley-Tuolumne Intrusive Suite Contacts...........................40

Taft Granite-Mt. Hoffman Granodiorite Contact................................41

Tuolumne Peak Granodiorite Contacts.....................................42

Yosemite Creek Granodiorite Contacts......................................42

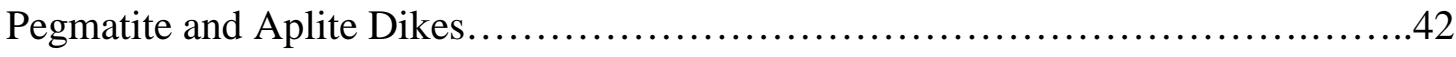

Ductile Shear Zones..........................................................43

Microstructures in Plutonic Rocks Outside of Ductile Shear Zones..................46

Structure in Metasedimentary Rocks.............................................48

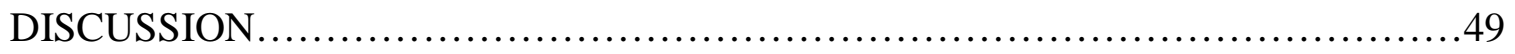

Construction of Plutons...............................................................

Yosemite Valley Intrusive Suite..............................................51

Mt. Hoffman Granodiorite............................................51

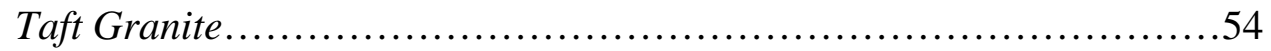

Tuolumne Peak Granodiorite..................................................55

Yosemite Creek Granodiorite................................................56

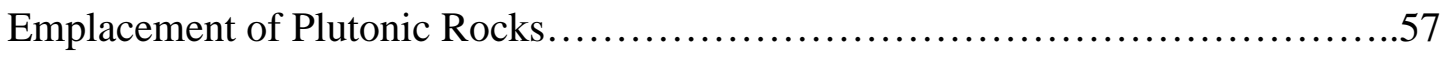

Stoping and Assimilation...................................................58

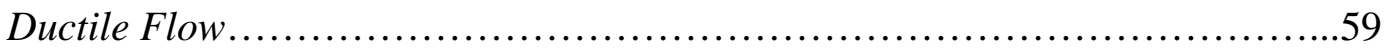

Roof Uplift/Floor Depression..............................................60

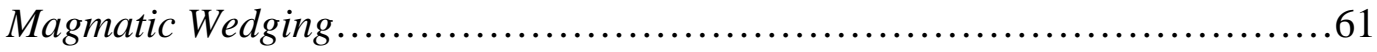

Tectonically Controlled Emplacement.........................................62 
Origin of Magmatic Foliation Orientation.....................................63

Mt. Hoffman Granodiorite.............................................63

Taft Granite.........................................................66

Yosemite Creek and Tuolumne Peak Granodiorite............................66

Development of Shear Zones.............................................67

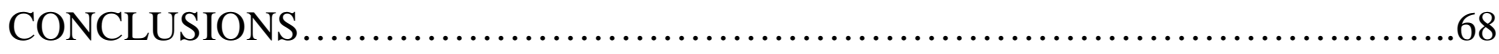

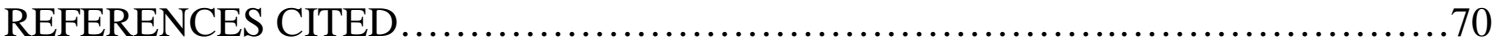




\section{LIST OF FIGURES}

Figure

1. Map of Central Sierra Nevada Batholith........................................4

2. Photomicrograph (Cross-polars) of Quartz-Sillimanite Schist.......................11

3. Photomicrograph (Cross-polars) of Mt. Hoffman Granodiorite......................14

4. Schlieren in Mt. Hoffman Granodiorite........................................16

5. Photomicrograph (Cross-polars) of Tonalitic Rock in Mt. Hoffman Granodiorite......17

6. Block of Mt. Hoffman Granodiorite in Tonalitic Body............................19

7. Photomicrograph (Cross-polars) of Taft Granite...............................21

8. Small Xenoliths of Taft Granite in Mafic Body..................................23

9. Block of Taft Granite Enclosed in Mafic Body..................................24

10. Tonalitic Dike in Taft Granite..............................................26

11. Photomicrograph (Cross-polars) of Porphyritic Tuolumne Peak Granodiorite........28

12. Photomicrograph (Cross-polars) of Medium-grained Yosemite Creek

Granodiorite.............................................................. 30

13. Photomicrograph (Cross-polars) of Porphyritic Yosemite Creek Granodiorite........32

14. Simplified geologic Map Emphasizing Magmatic Foliations in Study Area..........35

15. Geologic Map Emphasizing Lineation in Study Area............................39

16. Geologic Map Emphasizing Shear Zones in Study Area..........................44

17. Protomylonitic Mt. Hoffman Granodiorite in Shear Zone........................45 


\section{LIST OF TABLES}

Table

1. Rock Units within the Study Area with Abbreviated Description....................9 


\section{LIST OF PLATES}

Plate

1. Geologic Map and Cross-sections of Parts of Falls Ridge and Ten Lakes

Quadrangles, Northwestern Yosemite National Park, California.............. in pocket 


\section{INTRODUCTION}

The study of plutons provides extensive opportunity to gain a better understanding of magmatic systems, including the construction and material transfer processes operating during emplacement. Plutons also provide important insight into local and regional strain. The ubiquity of plutonic systems through time allows for a more complete understanding of the geologic history of a given region. Field observations of plutons and surrounding country rock, therefore, engender a discussion of magmatic movement and material transfer necessary to accommodate large volumes of magma during emplacement.

The terminology associated with magmatic systems (magma, magma chamber, pluton, etc.) commonly lacks consistency in the literature, and in this study I follow the definitions proposed by Miller et al. (2011). They define magma as a material with sufficient melt to be eruptible while potentially containing crystals and magma chamber as a continuous zone of eruptible magma at depth. A pluton is considered a continuous exposure of intrusive igneous rock that was constructed via a single magmatic system and in a geologically short period of time of less than a few million years (Miller et al., 2011).

Mechanisms for magma ascent and subsequent emplacement have been extensively debated in the geologic community. Many researchers have turned away from the formerly widely held hypothesis that assembly of plutons occurs via a few voluminous pulses of magma (e.g., Bateman and Chappell, 1979), in favor of construction via a series of relatively small injections (e.g., Pitcher and Berger, 1972; 
Wiebe and Collins, 1998; Miller and Paterson, 2001; Coleman et al., 2004; Glazner et al., 2004; Matzel et al., 2006; Miller et al., 2011; Paterson et al., 2011; Saint Blanquat et al., 2011). Many field observations, such as widespread compositional and textural heterogeneity and sheets, may be best explained by incremental assembly of plutons. In addition, the transfer of rock during emplacement may be easier if construction of plutons occurred via multiple increments (e.g., Paterson and Tobisch, 1992; Coleman et al., 2004).

Magmatic fabrics in plutons are excellent recorders of strain, and much can be interpreted from foliation patterns. Magmatic foliation in plutons has been attributed to varying combinations of pluton construction and emplacement, and regional strain (Paterson et al., 1998). Regional strain is likely recorded where foliation is consistent across plutonic bodies and strikes at a high angle to contacts and parallel to regional hostrock fabric (e.g., Paterson et al., 1998). Alternatively, margin-parallel (“onion skin”) foliation is compatible with strain associated with emplacement against country rock, or realignment as younger magmatic increments were emplaced. Foliation orientations may also result from a combination of regional strain and magmatic processes, complicating interpretation.

This thesis strives to address some of the above issues, utilizing a part of the central Sierra Nevada batholith as a case study. Observation and interpretation of structures in the study area, as well as relationships between units, provide insight into plutonic processes and regional strain. 


\section{Geologic Setting}

The Sierra Nevada batholith, a 640 km long expanse of Mesozoic plutons underlying most of the Sierra Nevada Mountains (Fig. 1), has played host to a number of studies on the structure and emplacement of plutons. The 94-85 Ma Tuolumne Intrusive Suite in Yosemite National Park has been one of the most extensively studied components of the batholith and has provided significant insights into the assembly and structure of plutons (e.g., Bateman and Chappell, 1979; Stern et al., 1981; Bateman, 1992; Coleman et al., 2004; Zak and Paterson, 2005; Memeti et al., 2010b). The Yosemite Valley Intrusive Suite, which is composed of older Cretaceous plutonic rocks and lies directly west of the Tuolumne Intrusive Suite, has been studied in much less detail, and provides an opportunity to expand on the current understanding of the construction, emplacement and structure of plutons in the Sierra Nevada batholith.

The Yosemite Valley and Tuolumne Intrusive Suites intrude metasedimentary host rocks in the study area. Pendants are found primarily along the contact between the suites, and locally as xenoliths within several meters of this contact. Metasedimentary rocks are dominantly quartz-biotite schists and biotite-rich quartzites. These rocks are compositionally similar to those of the May Lake pendant, $\sim 6 \mathrm{~km}$ to the south of the study area, and to the Snow Lake pendant, 15 km to the north (Fig. 1). The Snow Lake pendant is interpreted to have its origins in Precambrian to Cambrian miogeoclinal strata from the Mojave Desert or the southern Sierra Nevada Mountains (Lahren and Schweickert, 1989; Grasse et al., 2001; Memeti et al., 2010a). 


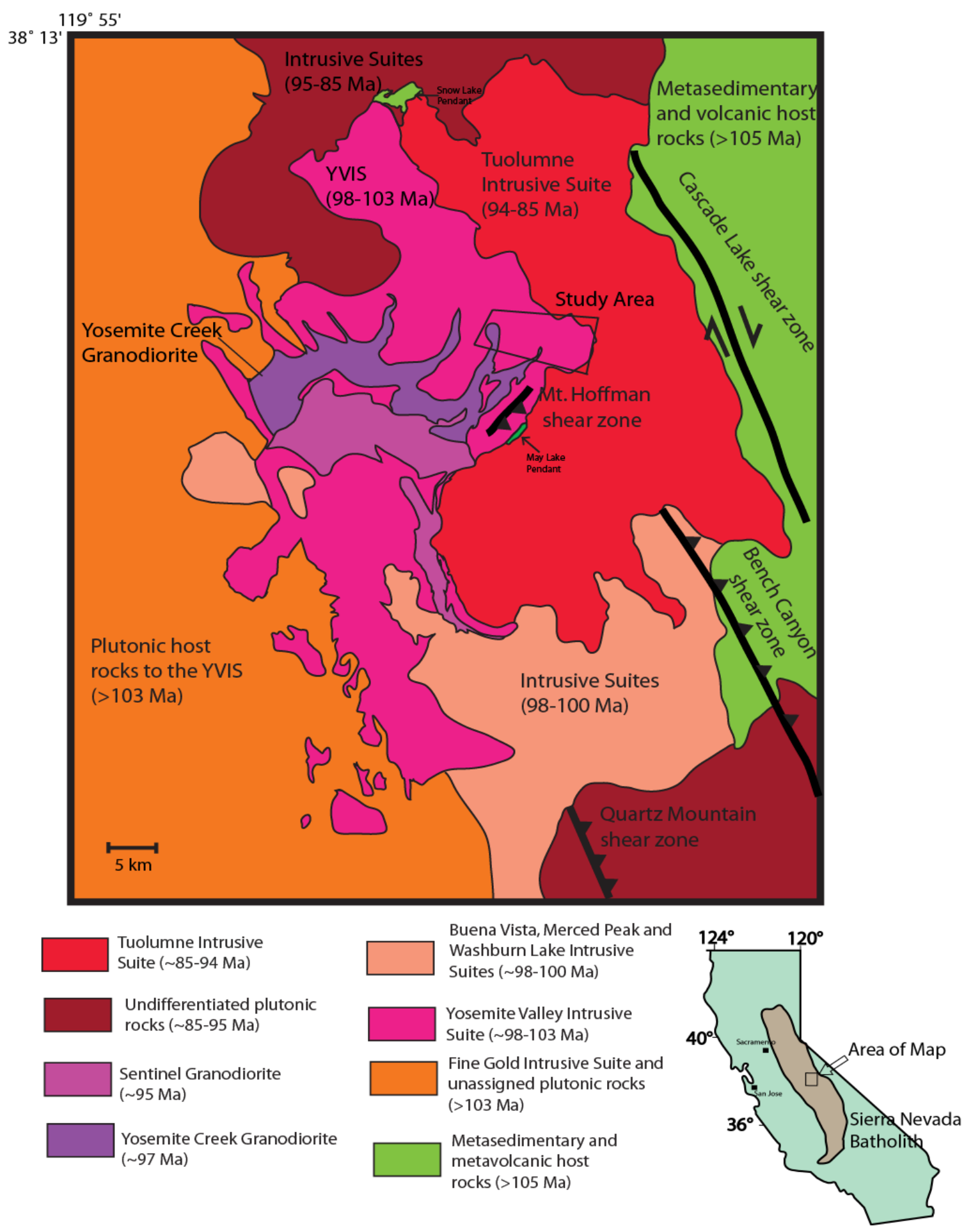

Figure 1. Map of the central Sierra Nevada batholith. Modified from Huber et al. (1989). Shear zones from Tobisch et al. (1995), Tikoff and Greene (1997), and Johnson (2013). 
Dextral displacement along the proposed Mojave-Snow Lake fault resulted in 200-400 $\mathrm{km}$ of translation bracketed between $148 \mathrm{Ma}$ and $110 \mathrm{Ma}$ (Lahren and Schweickert, 1989).

The oldest plutonic rocks in the area are those of the 103-98 Ma (Stern et al., 1981; Ratajeski et al., 2001; Taylor, 2004) Yosemite Valley Intrusive Suite. This suite includes the El Capitan Granite, which has been subdivided into the Mt. Hoffman granodiorite and Double Rock Granodiorite in the study area, and the younger Taft Granite. Metasedimentary and Yosemite Valley rocks were intruded by the $\sim 97 \mathrm{Ma}$ Yosemite Creek Granodiorite (Burgess et al., 2009) and the Granodiorite North of Tuolumne Peak (poorly bracketed at 102-97 Ma). A small portion of the 94-85 Ma Tuolumne Intrusive Suite (e.g., Coleman et al., 2004; Matzel et al., 2005; Burgess et al., 2009; Memeti et al., 2010b) is exposed along the eastern margin of the study area, but is not a major focus of this study.

\section{Previous Work}

Kistler (1973) and Bateman et al. (1983) completed the most detailed mapping of the study area, at a scale of 1:62,500, of the Hetch Hetchy and Tuolumne 15' Quadrangles, respectively. Huber et al. (1989) later compiled the maps to produce a 1:125,000 scale geologic map of Yosemite National Park. Areas southwest of the study area have been mapped by two M.S. students of San Jose State University. Petsche (2008) provided detailed mapping of the Yosemite Valley Intrusive Suite, southernmost 
Yosemite Creek Granodiorite, and particularly the younger Sentinel Granodiorite. Johnson (2013) studied the Yosemite Valley Intrusive Suite and Yosemite Creek Granodiorite in the Ten Lakes area, directly to the southwest of the study area. Mapping of sections in the easternmost part of the study area, straddling the contact between the Yosemite Valley Intrusive Suite and the Tuolumne Intrusive Suite, has been conducted by Robert Miller and colleagues Jonathan Miller and Scott Paterson. Geochemical and petrologic studies have been completed on the El Capitan Granite and Taft Granite in Yosemite Valley by Ratajeski et al. (2001), who have proposed a genetic relationship between the two units.

\section{Study Area}

The study area encompasses a $\sim 50 \mathrm{~km}^{2}$ region of Yosemite National Park in parts of the Falls Ridge and Ten Lakes 7.5 minute quadrangles (Plate 1 and Fig. 1). Parts of the area, particularly in the canyon of the Tuolumne River, were not studied in detail due to difficult accessibility. Rocks of the Yosemite Valley Intrusive Suite, and to a lesser extent those of the Yosemite Creek Granodiorite and Granodiorite North of Tuolumne Peak (hereafter informally referred to as the Tuolumne Peak granodiorite), were the focus of investigation. The Tuolumne Intrusive Suite also extends approximately $1 \mathrm{~km}$ into the eastern part of the study area and has been mapped in an effort to better understand the relationship between this suite and the Yosemite Valley Intrusive Suite. Metasedimentary bodies have also been mapped within the study area. 


\section{Methods}

The aim of this thesis is to examine the structure, construction, and emplacement processes of plutons within the central Sierra Nevada batholith, and also contribute to the general understanding of plutonic systems. Six weeks of outcrop analysis and geologic mapping, at a scale of 1:24,000, were completed to complement the existing, less detailed geologic maps of the region. Contacts between units and internal contacts were mapped and described. Magmatic and solid-state foliation and lineations were measured and compiled to ascertain structural patterns. Relationships between foliation strike and strike of contacts were interpreted to determine if foliation resulted from internal magmatic processes or regional deformation. Solid-state shear zones recording local and regional deformation were measured. Enclaves, schlieren, dikes, and mafic bodies were described in detail. Thin-section descriptions of mineral textures and microstructures were also completed.

\section{ROCK UNITS}

Rocks in the study area include metasedimentary host rocks, units of the Yosemite Valley Intrusive Suite, including the Mt. Hoffman granodiorite, Double Rock Granodiorite, and Taft Granite, as well as the younger Tuolumne Peak granodiorite and the Yosemite Creek Granodiorite, and a small area of the Tuolumne Intrusive Suite. 
Main units of the study area are briefly summarized in Table 1, with more detailed descriptions following.

\section{Metasedimentary Rocks}

Several map-scale bodies and dozens of xenoliths of metasedimentary rocks are present along the contact between the Yosemite Valley Intrusive Suite and younger Tuolumne Intrusive Suite (Plate 1). Map-scale bodies are typically elongate and have steeply dipping contacts. The trend of the long axis of the metasedimentary bodies in map view varies as the contact between the Yosemite Valley Intrusive Suite and Tuolumne Intrusive Suite swings through a series of nearly $90^{\circ}$ bends in the large salient of Yosemite Valley rocks in the eastern part of the study area (Plate 1 and Fig. 1).

The size of the map-scale metasedimentary bodies varies considerably, with the largest, the pendant at McGee Lake, extending for $1.5 \mathrm{~km}$ and having an average width of $\sim 100 \mathrm{~m}$. A second sizable body lies near the southern boundary of the study area and is elongate in a north-south direction. This body is $\sim 1.25 \mathrm{~km}$ long and has an average

width of $100 \mathrm{~m}$. Other metasedimentary bodies range in size from 250 m by $100 \mathrm{~m}$ to as small as $\sim 10 \mathrm{~m}$ by $5 \mathrm{~m}$.

The metasedimentary rocks are dominantly fine- to medium-grained biotite schist and biotite-rich quartzite. Both rock types occur within large bodies as alternating coarse-grained, quartz-rich layers and fine-grained, biotite-rich layers that range in thickness from $0.25 \mathrm{~mm}$ to several meters. 
Table 1. Rock units within the study area with abbreviated description. CI= Color Index.

\begin{tabular}{|c|c|c|}
\hline Rock Unit & Age & Description \\
\hline Metasedimentary host rock & $\begin{array}{l}\text { Pre-Cambrian to } \\
\text { Cambrian } \\
\text { protoliths }\end{array}$ & $\begin{array}{l}\text { Fine- to medium-grained biotite } \\
\text { schist and biotite-rich quartzite }\end{array}$ \\
\hline Yosemite Valley Intrusive Suite & $103-98 \mathrm{Ma}$ & \\
\hline \multicolumn{3}{|l|}{ El Capitan Granite } \\
\hline Mt. Hoffman granodiorite & $\begin{array}{l}\text { 102.7 Ma (Taylor, } \\
\text { 2004) }\end{array}$ & $\begin{array}{l}\text { Medium to coarse- grained } \\
\text { granodiorite to granite; } \mathrm{Cl}=7-15\end{array}$ \\
\hline Double Rock Granodiorite & & $\begin{array}{l}\text { Coarse-grained, porphyritic, } \\
\text { biotite-rich granodiorite; } \mathrm{Cl}=7 \\
\text { (Kistler, 1973) }\end{array}$ \\
\hline Taft Granite & 102-98 Ma & $\begin{array}{l}\text { Coarse-grained granite; minor } \\
\text { fine-grained garnet; generally } \\
\text { homogenous; } \mathrm{Cl}=\sim 5\end{array}$ \\
\hline Tuolumne Peak granodiorite & $\sim 102-97 \mathrm{Ma}$ & $\begin{array}{l}\text { Fine-grained, porphyritic } \\
\text { granodiorite; } \mathrm{Cl}=\sim 10\end{array}$ \\
\hline Yosemite Creek Granodiorite & $\begin{array}{l}\text { 97 Ma (Burgess } \\
\text { et al., 2009) }\end{array}$ & $\begin{array}{l}\text { Granodiorite to tonalite; } \\
\text { texturally variable with } 3 \\
\text { subunits } \mathrm{Cl} 12-35\end{array}$ \\
\hline Medium-grained granodiorite & & $\begin{array}{l}\text { Exposed in southern part of } \\
\text { area; } \mathrm{Cl}=12\end{array}$ \\
\hline Porphyritic granodiorite & & $\begin{array}{l}\text { Characterized by } 1 \mathrm{~cm} \text {, euhedral } \\
\text { plagioclase; exposed in western } \\
\text { part of area; } \mathrm{Cl}=15\end{array}$ \\
\hline Tonalite & & $\begin{array}{l}\text { Medium-grained, equigranular; } \\
\text { exposed in western part of area; } \\
\mathrm{Cl}=\sim 30-35\end{array}$ \\
\hline Tuolumne Intrusive Suite & 94-85 Ma & \\
\hline Glen Aulin Tonalite & & $\begin{array}{l}\text { Medium-grained granodiorite to } \\
\text { tonalite in study area; } \mathrm{Cl}=20-30\end{array}$ \\
\hline
\end{tabular}


Biotite makes up 20-40\% of the schist, and has an average length of $\sim 0.25 \mathrm{~mm}$. The schist contains $\sim 25-45 \%$ quartz with grain size ranging from 0.025 to $1.5 \mathrm{~mm}$ and averaging $\sim 1 \mathrm{~mm}$. Quartz grains generally contain abundant subgrains and form mosaics, particularly in fine-grained layers. Potassium feldspar and plagioclase make up 5-10\% and $10-15 \%$ of the schist, respectively. In several samples, iron oxides compose up to $10 \%$ of the rock. Foliation in the biotite schist is well defined by aligned biotite, iron oxide grains and elongate quartz.

Quartzite is composed of 85-95\%, 0.025-1.5 mm-long quartz. Biotite, plagioclase and potassium feldspar combined constitute between 5-15\% of the rock. The pendant at McGee Lake is mainly composed of biotite schist and biotite-rich quartzite, but also contains a small area of quartz-sillimanite schist (Fig. 2). This rock consists of $\sim 65 \%$, fine- to medium-grained, typically elongate quartz grains that range in size from 0.2 by $0.25 \mathrm{~mm}$ to 0.4 by $1.5 \mathrm{~mm}$. Quartz exhibits well-developed checkerboard subgrains. Sillimanite composes $\sim 30 \%$ of the schist, ranges in size from 0.1 by $0.25 \mathrm{~mm}$ to 0.25 by $2 \mathrm{~mm}$, and includes fibrolite in some rocks. Fine-grained muscovite and iron oxides are also present in approximately equal amounts and make up $\sim 5 \%$ of the rock. Sillimanite grains are elongate parallel to the dominant foliation.

Two fabrics are evident in thin-section; the dominant one is parallel to the contact between the Yosemite Valley Intrusive Suite and Tuolumne Intrusive Suite, and the second is at an angle of $\sim 30^{\circ}$ to the contact. As the pendant at McGee Lake is relatively small, it is speculative to draw conclusions about the origin of the two foliations. 


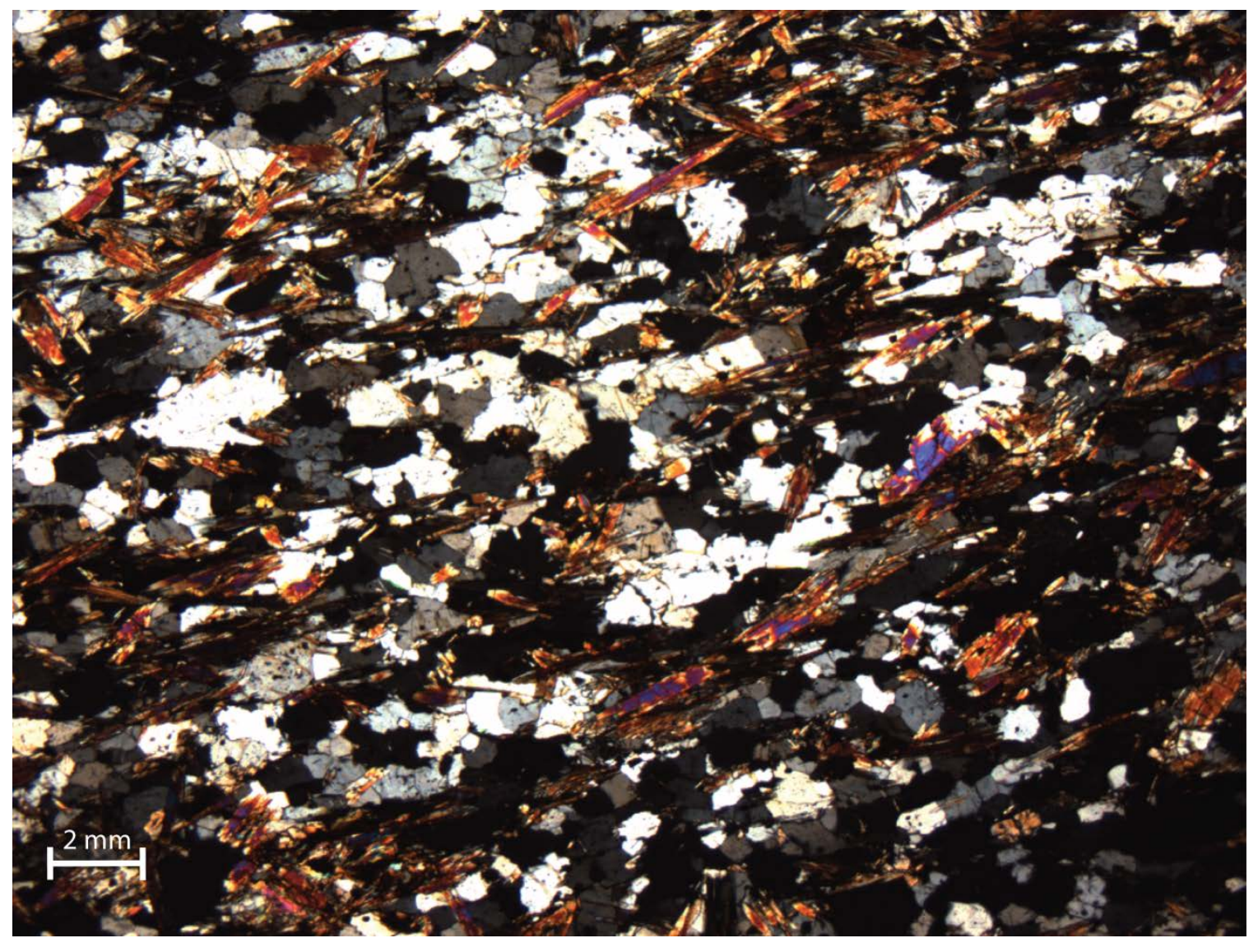

Figure 2. Photomicrograph (cross-polars) of quartz-sillimanite schist. Sample from the McGee Lake metasedimentary pendant. Note foliation defined by sillimanite (prominent elongate grains) and elongate quartz grains. 
Nevertheless, they may have formed in response to emplacement of the surrounding plutons, which are of different age, and/or due to Mesozoic regional deformation.

The southernmost pendant in the study area is dominated by quartz-biotite schist, but fine-grained quartz-muscovite-biotite-sillimanite schist occurs in at least one location. The latter rock is composed of $\sim 45 \%$ quartz, ranging in size from 0.25 to $1 \mathrm{~mm}$, and averaging $\sim 0.5 \mathrm{~mm}$. Quartz grains are typically subhedral, contain well-developed checkerboard subgrains, and locally display prominent grain boundary migration recrystallization as indicated by irregular, jigsaw-like grain boundaries. Muscovite makes up $\sim 35 \%$ of the rock, and has an average grain size of 0.2 by $0.5 \mathrm{~mm}$. In thinsection, muscovite defines fold hinges with axes at a moderate angle to lineation. Finegrained biotite, 0.1 to $0.25 \mathrm{~mm}$ long, constitutes up to $15 \%$ of the schist, and is variably altered to chlorite. Sillimanite makes up $~ 5 \%$ of the rock, and is typically blocky. The blocky grains range from 0.25 to $0.5 \mathrm{~mm}$ with several elongate, typically larger grains also present. Sillimanite has irregularly shaped grain boundaries and encloses quartz.

\section{Yosemite Valley Intrusive Suite}

The 103-98 Ma Yosemite Valley Intrusive Suite is composed of the Mt. Hoffman granodiorite, Double Rock Granodiorite, and Taft Granite (Huber et al., 1989; Bateman, 1992). Rocks of the Yosemite Valley Suite intrude metasedimentary rocks described above, as well as older plutonic rocks exposed west of the study area. 


\section{Mt. Hoffman Granodiorite and Associated Mafic Bodies}

The $102.7 \pm 0.3$ Ma Mt. Hoffman granodiorite (Taylor, 2004) is typically a coarse-grained, porphyritic granite to granodiorite with a color index (CI) of 7-15 that dominates the easternmost part of the study area (Plate 1). Enclaves, schlieren, and mafic bodies are found throughout the granodiorite. The granodiorite is intruded on three sides by the younger Tuolumne Intrusive Suite, and is intruded to the west by the Taft Granite. Compositional and textural variations occur throughout the Mt. Hoffman granodiorite in the study area, but mapable subunits have not been recognized.

The Mt. Hoffman granodiorite consists mostly of plagioclase (35-50\%), quartz (20-30\%), potassium feldspar (20-30\%), and biotite (7-15\%) (Fig. 3). Tabular plagioclase grains range from $0.5-8 \mathrm{~mm}$ and average $4 \mathrm{~mm}$ in length. Crystals locally form phenocrysts. Normal zoning is common and oscillatory zoning occurs locally. Approximately 5-15\% of plagioclase grains are myrmekitic and deformation twinning is ubiquitous. Anhedral quartz ranges from 2-10 $\mathrm{mm}$ in diameter and averages $4 \mathrm{~mm}$. Checkerboard sub-grains and recrystallized grains, with polygonal grain boundaries, are widespread in thin-section. Quartz locally encloses plagioclase. Potassium feldspar ranges in length from $0.5-10 \mathrm{~mm}$ and averages $4 \mathrm{~mm}$. Crystals are typically euhedral and locally form phenocrysts that enclose biotite and quartz. Carlsbad twinning, scotch-plaid twinning and perthite are ubiquitous with seritization common. Biotite is $0.5-4 \mathrm{~mm}$ in diameter, and averages $1 \mathrm{~mm}$. Chloritization is widespread, affecting $30-50 \%$ of biotite grains in some samples. Sphene comprises $<1 \%$ of the rock, and apatite, magnetite, ilmenite, zircon, and secondary epidote are present in trace amounts. 


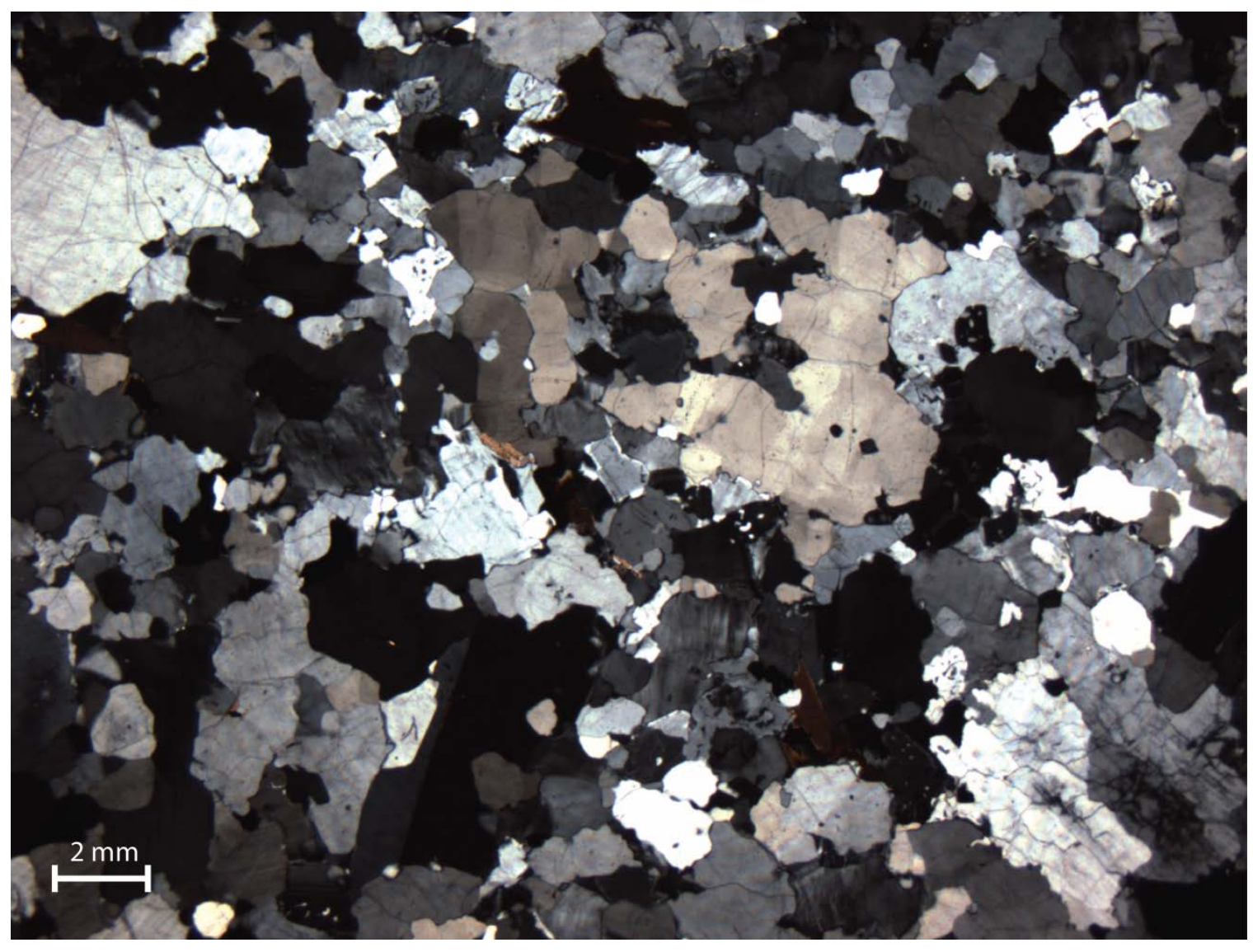

Figure 3. Photomicrograph (cross-polars) of Mt. Hoffman granodiorite. Sample represents porphyritic variety of the granodiorite. Note variation in grain size. 
Magmatic foliation is typically moderately well defined by alignment of biotite and locally by weakly aligned tabular plagioclase crystals. Local solid-state foliation is mainly defined by elongate quartz crystals.

Schlieren found in several locations in the Mt. Hoffman granodiorite contain mafic layers that strike generally east-west, have sharper southern boundaries, and become more diffuse to the north. Flame structures and trough cross-cutting relationships imply younging to the north (Fig. 4).

Several map-scale "mafic” bodies with zones of schlieren and enclave swarms occur within the Mt. Hoffman granodiorite and mingling relationships suggest that they are coeval with the granodiorite. These bodies are generally tonalitic in composition and are up to 5 by $8 \mathrm{~m}$. The tonalite is dominantly composed of plagioclase ( $50 \%)$, quartz (15-25\%), biotite (8-20\%), hornblende (10-15\%), and clinopyroxene ( 2\%) (Fig. 5). Tabular plagioclase ranges in length from 1 to $5 \mathrm{~mm}$, and averages $3 \mathrm{~mm}$. Crystals locally enclose hornblende and oscillatory zoning has been observed. Albite and deformation twins are ubiquitous and seritization is minor. Quartz is typically fine- to medium-grained, averaging $1 \mathrm{~mm}$ in length, with local phenocrysts up to $5 \mathrm{~mm}$. Bulging recrystallization and checkerboard subgrains are common. Biotite ranges in size from 0.5-7 mm, with an average of $2 \mathrm{~mm}$. Crystals are generally poikilitic, enclosing quartz, plagioclase, sphene and iron oxides. Chloritization is evident in up to $20 \%$ of crystals and kinking is common. Biotite commonly appears as the end product of a reaction series whereby clinopyroxene reacts to form hornblende, which in turn is altered to biotite presumably during chemical reequilibration as magma cooled. 


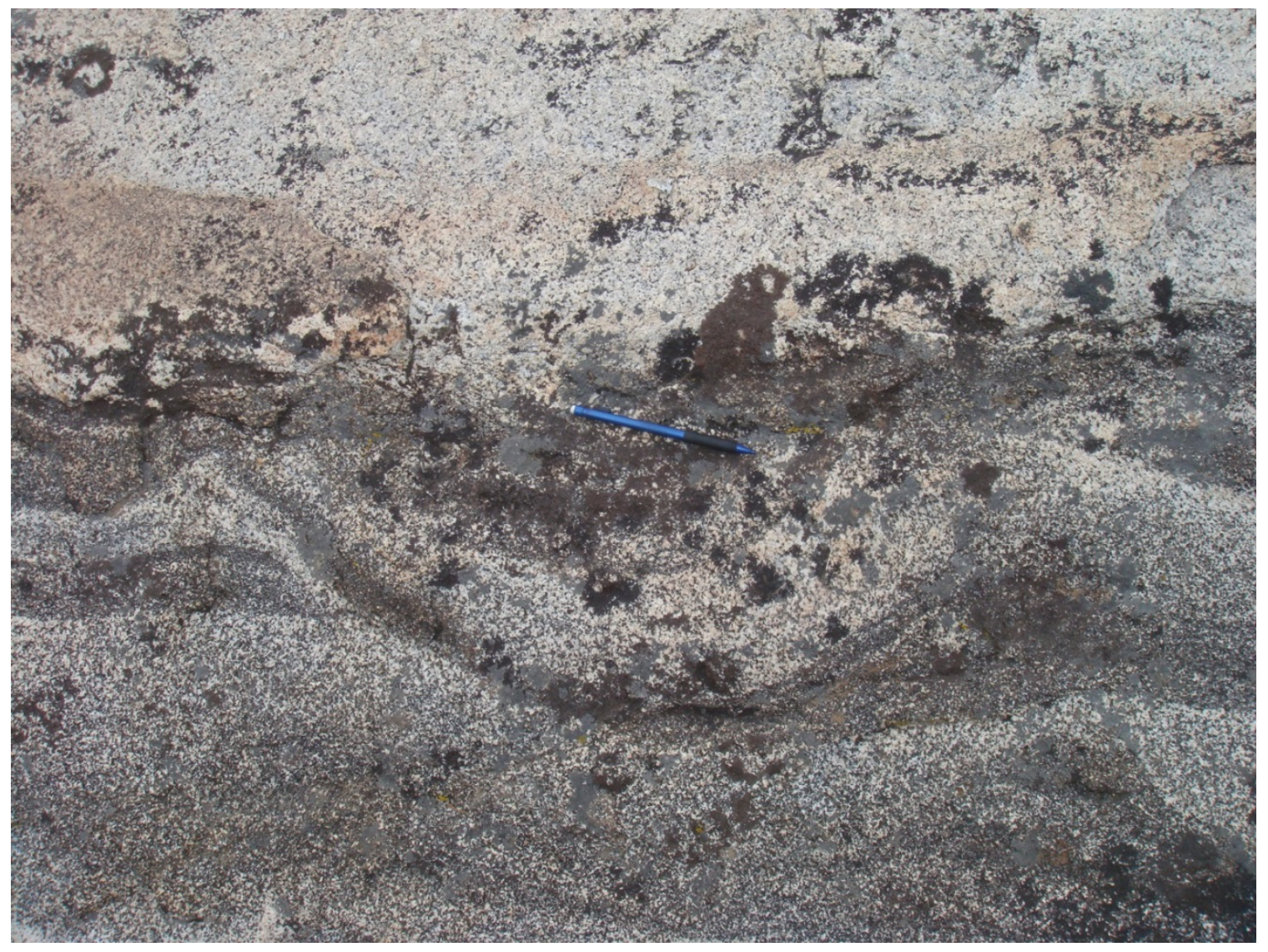

Figure 4. Schlieren in Mt. Hoffman granodiorite. Cross-cutting relationships indicate younging to the north (up). Pencil for scale. 


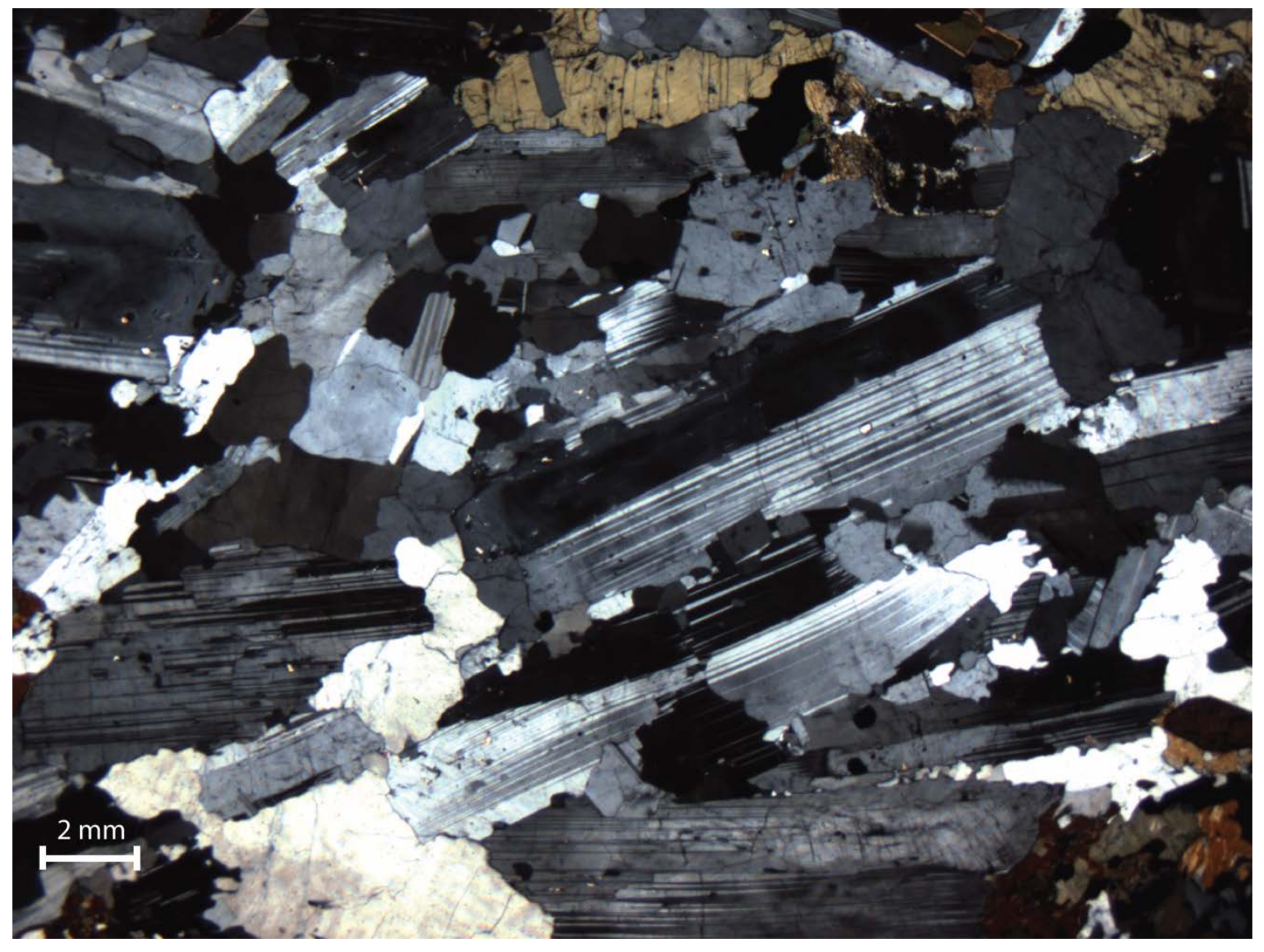

Figure 5. Photomicrograph (cross-polars) of tonalitic rock in Mt. Hoffman granodiorite. Note large, tabular plagioclase grains. 
Tabular hornblende ranges in length from 0.5 to $4 \mathrm{~mm}$, averages $1 \mathrm{~mm}$, and occurs almost exclusively at the expense of clinopyroxene. The original dimensions of the clinopyroxene are difficult to determine. Average grain size is $\sim 1 \mathrm{~mm}$, and grains range in length from 0.5-3 mm. Minor sphene is present. Apatite and iron oxides are accessories.

A tonalitic body with nearly identical compositional and textural properties as those described above occurs $\sim 5 \mathrm{~m}$ from a mafic body and associated schlieren along the Tuolumne River (Plate 1), but sharply intrudes and incorporates xenoliths of the surrounding Mt. Hoffman granodiorite (Fig. 6).

\section{Double Rock Granodiorite}

The Double Rock Granodiorite, which crops out in the western portion of the map area, is a coarse-grained, porphyritic, biotite granodiorite. This unit has not been dated, but is considered broadly related to and coeval with the El Capitan Granite of Yosemite Valley (Kistler, 1973), and therefore likely of an age similar to the 102.7 Ma Mt. Hoffman granodiorite (Taylor, 2004). Mafic enclaves are locally abundant and aligned tabular K-feldspar phenocrysts are prevalent throughout (Kistler, 1973). Limited access inhibited field investigation of this unit within the study area.

\section{Taft Granite}

The Taft Granite is a coarse-grained, homogenous granite distinguished by a low color index $(\sim 5)$ and ubiquitous, though minor, fine-grained garnet. 


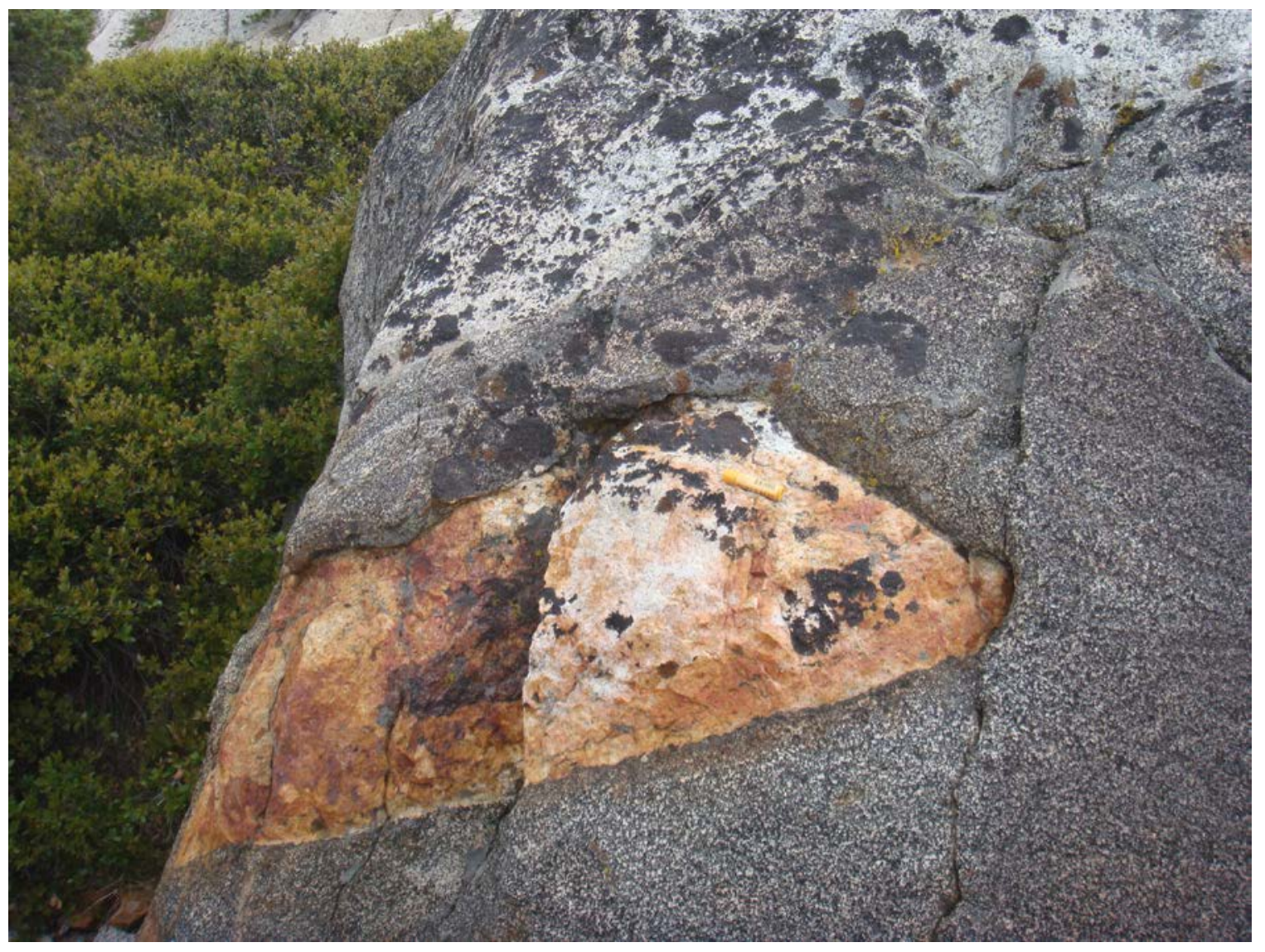

Figure 6. Block of Mt. Hoffman granodiorite in tonalitic body. Chapstick for scale. 
The granite makes up the majority of the study area and is exposed as a continuous body. Concordant $\mathrm{U}-\mathrm{Pb}$ zircon dates remain elusive for this granite despite several efforts to obtain an age. The age is bracketed between that of the older Mt. Hoffman granodiorite, at 102.7 +/- 0.2 Ma (Taylor, 2004), and the younger Yosemite Creek Granodiorite, at 97 Ma (Burgess et al., 2009). The Alaskite of Ten Lakes (Kistler, 1973) and Leucogranite of Ten Lakes (Bateman et al., 1983) are also included in this unit (Huber et al., 1989). Ratajeski et al. (2001) described the Taft Granite as typically medium-grained and associated with mafic enclaves, schlieren, and dikes, including the large dike complex of the North American wall of El Capitan in Yosemite Valley. In contrast, in the study area and in areas to the south (Johnson, 2013), the Taft Granite is typically coarse-grained and more homogenous than in Yosemite Valley, with minimal mafic enclaves, schlieren, and dikes. Several map-scale, petrographically distinct bodies are, however, enclosed within the granite in the study area and display varying contact relationships with the unit. Previous workers (Kistler, 1973; Bateman et al., 1983) have referred to these bodies as mafic, although the composition is typically tonalitic.

The Taft Granite is dominantly composed of potassium feldspar ( 40\%), quartz ( 30\%), plagioclase ( 25\%), and biotite ( 5\%) (Fig. 7). Subhedral to euhedral potassium feldspar crystals range in length from 0.2-4 mm and average $2 \mathrm{~mm}$. Perthite and tartan twins are present throughout the unit and myrmekitic texture is common. Recrystallized mosaics of potassium feldspar form locally and suggest moderate- to high-temperature recrystallization. Quartz ranges in length from $0.2-7 \mathrm{~mm}$, and averages $3 \mathrm{~mm}$. It is commonly poikilitic, enclosing plagioclase, biotite, and potassium feldspar. 


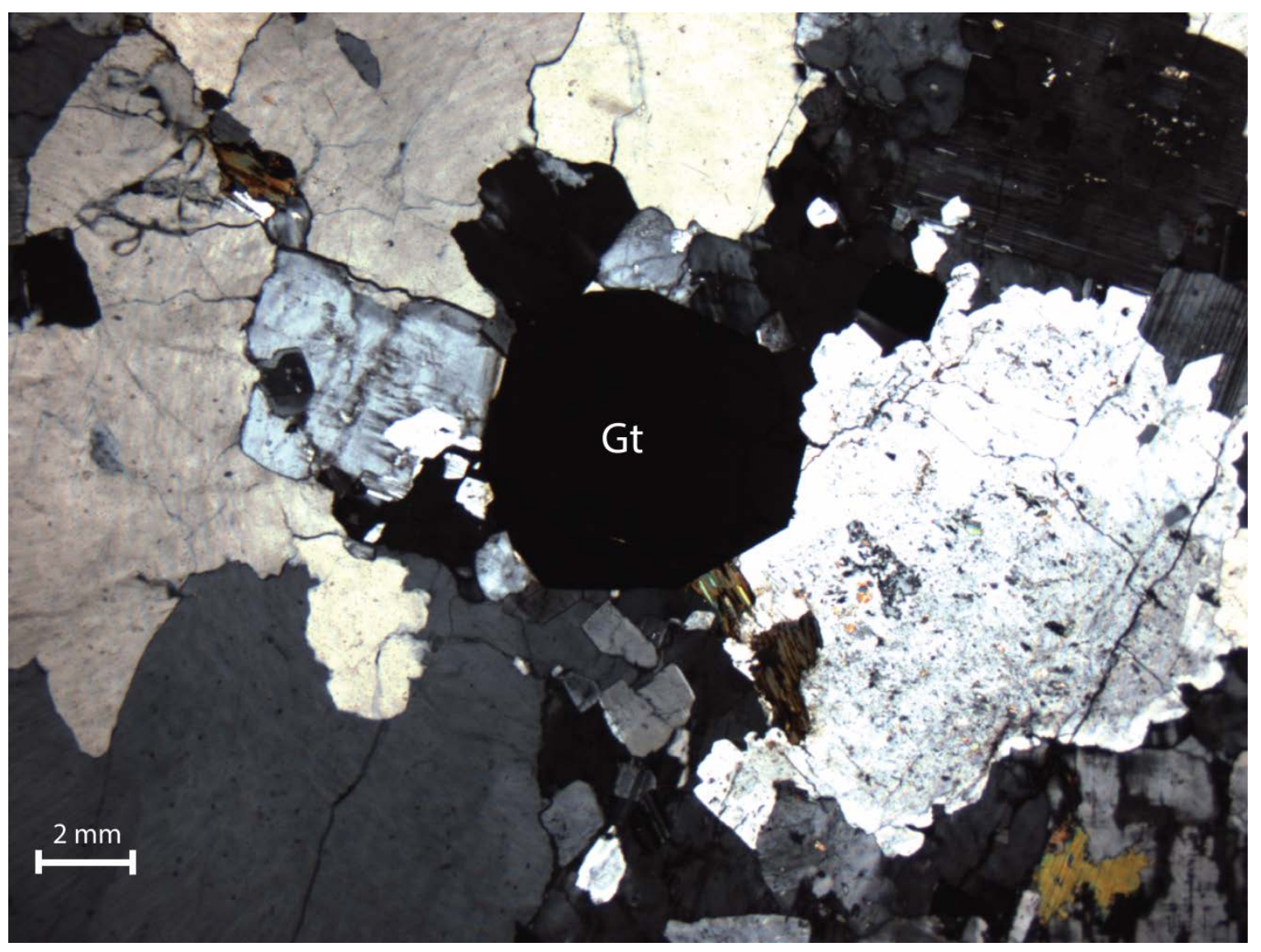

Figure 7. Photomicrograph (cross-polars) of Taft Granite. Note large, euhedral garnet (Gt) in center. 
Grains exhibit undulatory extinction and grain boundary migration recrystallization, and subgrains are evident. Subhedral plagioclase grains range in length from $0.25-4 \mathrm{~mm}$, and average $1 \mathrm{~mm}$. Albite twins are ubiquitous and grains are commonly kinked. Minor seritization and saussurization occur locally. Subhedral biotite ranges in length from 0.25-5 mm, and averages $1 \mathrm{~mm}$. Biotite grains are extensively chloritized and locally altered to sphene. Garnet, magnetite, ilmenite and zircon make up $<1 \%$ of the rock. Garnet appears to be more abundant adjacent to contacts, decreasing towards the center of the pluton. Secondary muscovite, epidote and sphene are present in trace amounts.

The map-scale, mafic bodies within the Taft Granite display variable contact relationships with the surrounding rock. The 100 by $20 \mathrm{~m}$ tonalite body $\sim 1 \mathrm{~km}$ west of the Taft Granite-Mt. Hoffman granodiorite contact (Plate 1) contains hornblende and plagioclase phenocrysts. The body has sharp contacts and locally encloses xenoliths of the granite. Xenoliths range in length from several centimeters to several meters and vary from subrounded to angular (Figs. 8-9). Disaggregation and mechanical incorporation of the Taft Granite into the tonalite is evident from 2-3-cm-long xenoliths with diffuse boundaries (Fig. 8).

Foliation in the Taft Granite is commonly weak to unmeasurable. Where measured, it has a highly variable strike and commonly dips steeply. Enclaves and schlieren are rare in the unit and those that were observed are variably oriented. Several fine- to medium-grained mafic dikes were measured in the study area and are $6-10 \mathrm{~cm}$ wide, extend for 1-5 m, dip moderately, and strike southwest. 


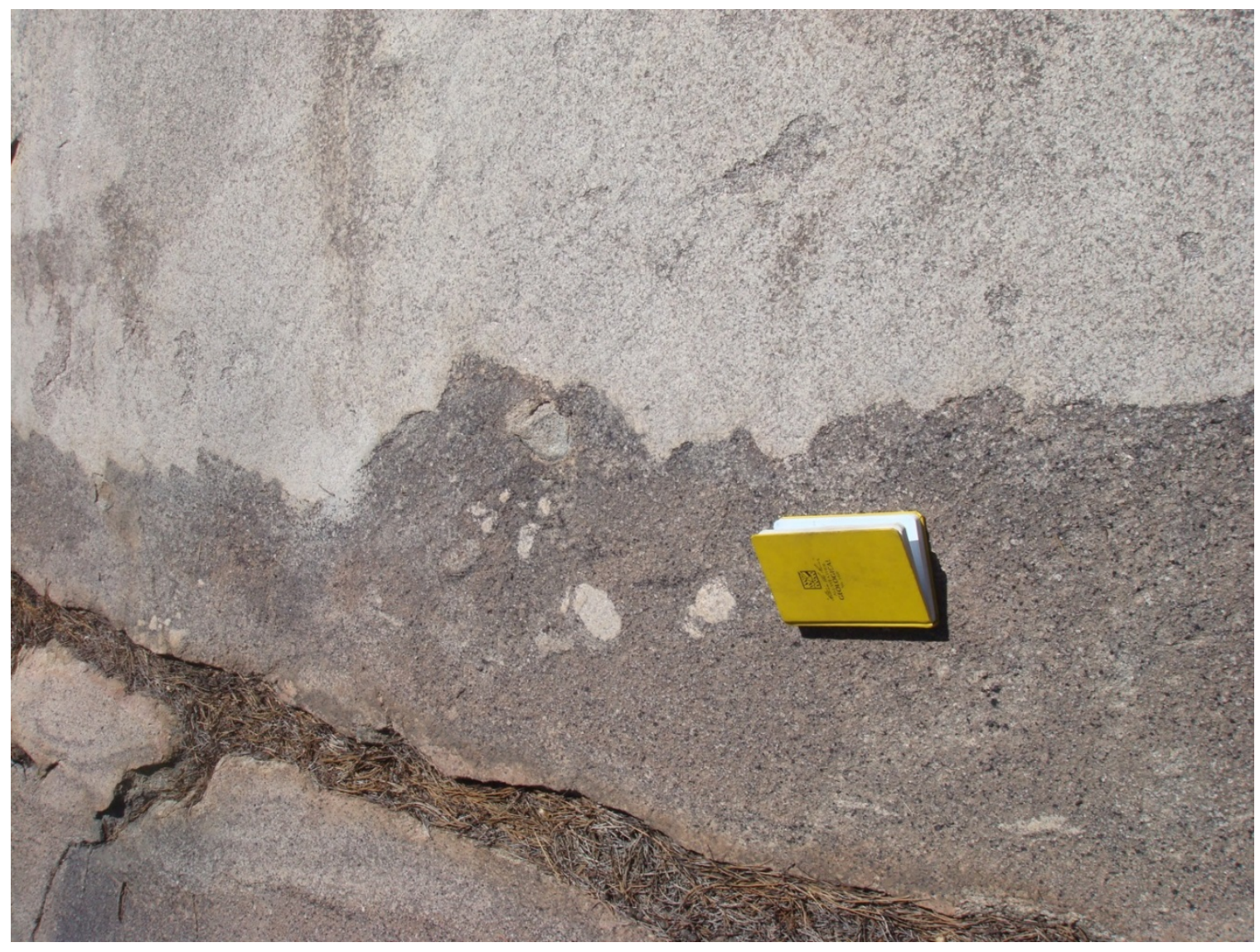

Figure 8. Small xenoliths of Taft Granite in mafic body. Note rounding of xenoliths and cuspate-lobate contact between granite and mafic body. 


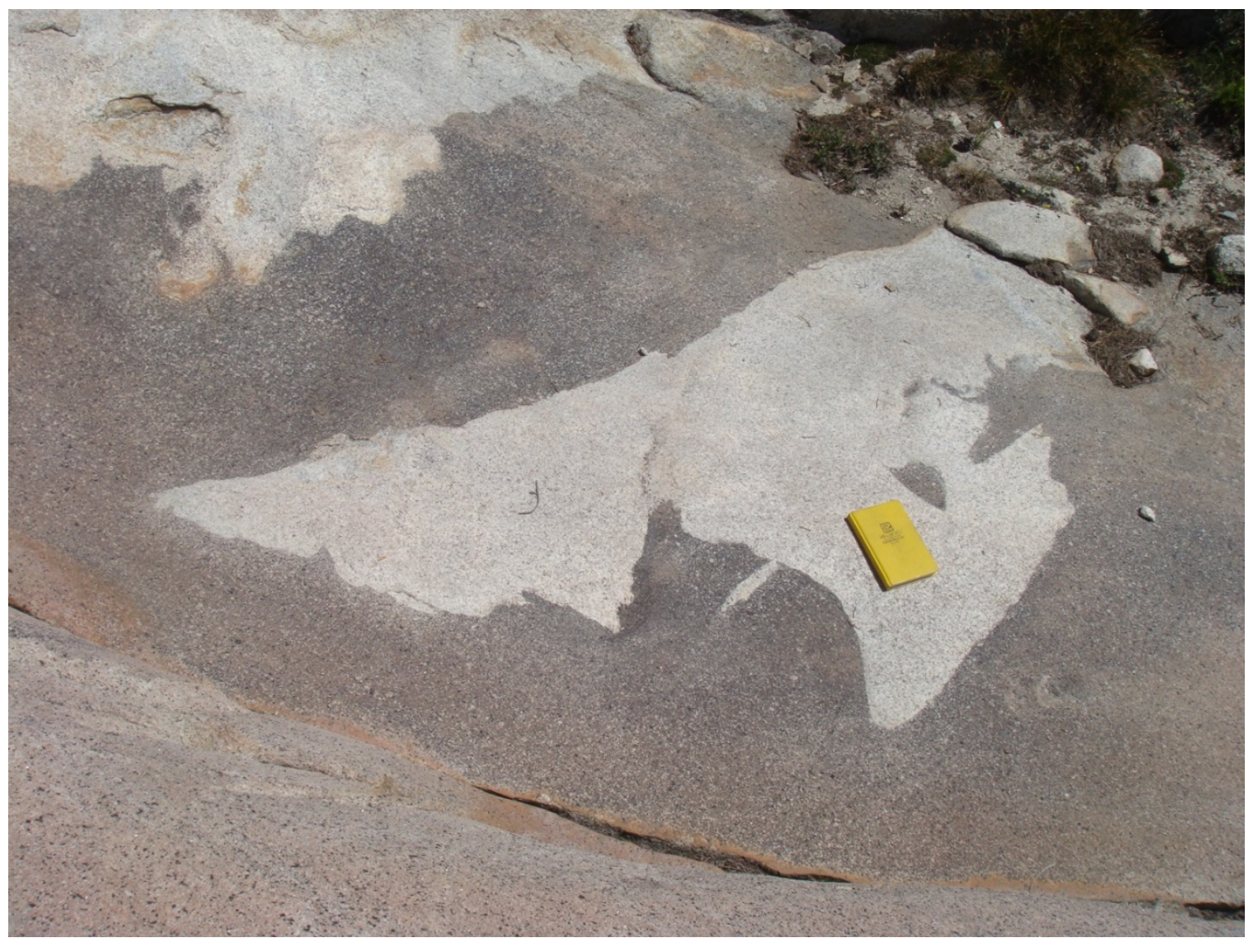

Figure 9. Block of Taft Granite enclosed in mafic body. Angular contacts between units suggest high rheological contrast. 
The dikes are fine- to medium-grained diorite. Diffuse boundaries with the host rocks indicate that dikes are co-magmatic with the Taft Granite.

Aplitic and pegmatitic dikes were not observed. An $18 \mathrm{~cm}$-wide dike with sinuous boundaries has a higher color index than "typical” Taft Granite, and is porphyritic, a texture not observed elsewhere in the unit (Fig. 10). The dike appears to be folded and magmatically faulted (Fig. 10). The contact with the surrounding granite is diffuse, suggesting co-magmatism.

The few enclaves observed in the Taft Granite are in small swarms along the contact with the Mt. Hoffman granodiorite. Enclaves are fine-grained and have the same minerals as the granite, but contain larger (3-4 mm in diameter) euhedral garnets and have a higher color index. Enclaves are 3-5 cm long and 2-5 cm wide.

\section{Tuolumne Peak Granodiorite}

The Tuolumne Peak granodiorite has been mapped as a hornblende-biotite granodiorite that intrudes the Taft Granite in the southernmost portion of the study area as a series of irregularly shaped masses and dikes (Bateman et al., 1983). The granodiorite commonly incorporates meter-scale, angular xenoliths of the granite. Dikes of the Yosemite Creek Granodiorite intrude the unit, indicating that the age of the Tuolumne Peak rocks is bracketed between intrusion of the Yosemite Creek and Taft rocks. 


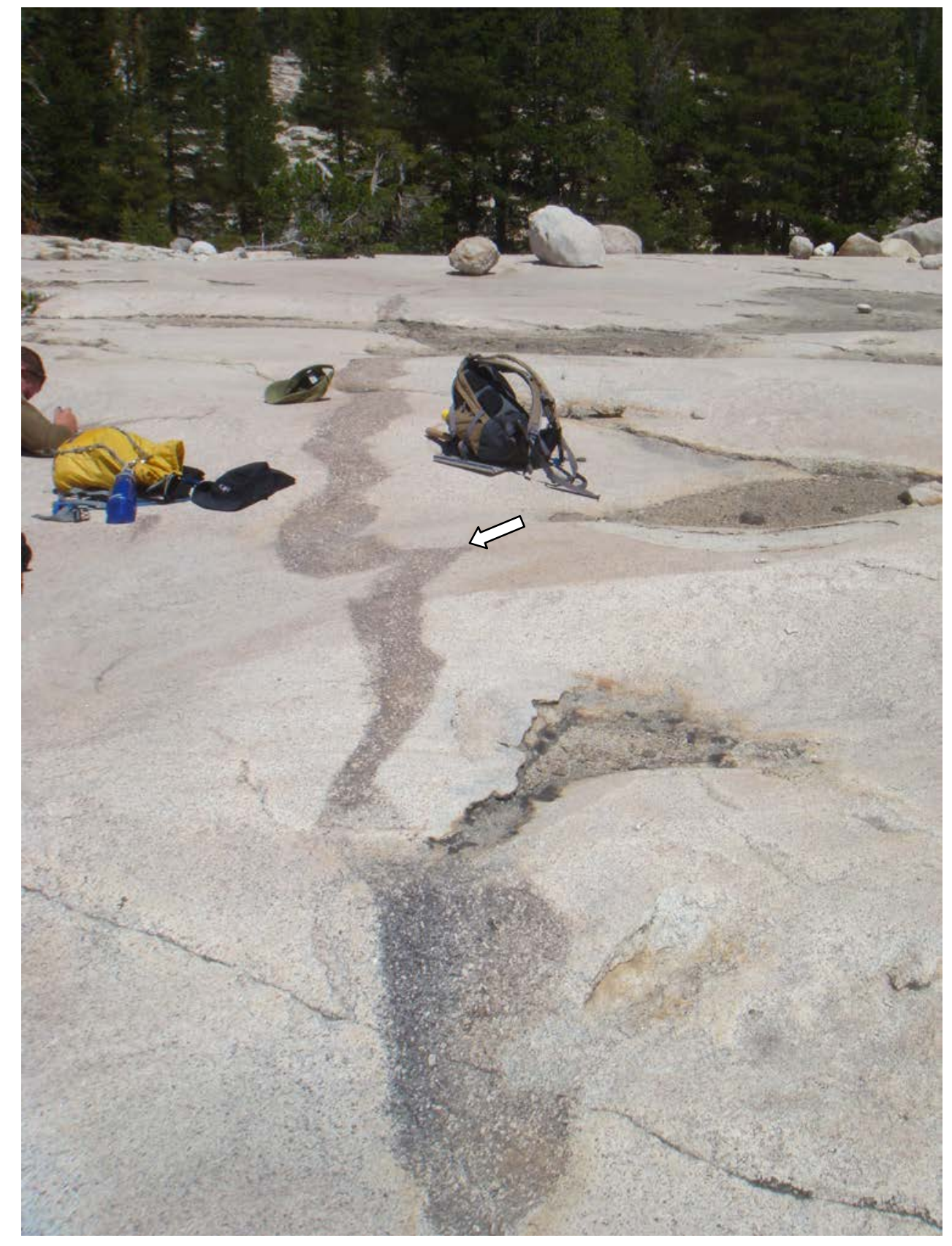

Figure 10. Tonalitic dike in Taft Granite. Note folds and magmatic fault (indicated by arrow). 
All contacts are sharp, suggesting that the Tuolumne Peak granodiorite is not comagmatic with other units. Aplitic and pegmatitic dikes were not observed.

Within the study area, the Tuolumne Peak granodiorite is a fine-grained, porphyritic granodiorite with a color index of $\sim 10$ and is dominantly composed of plagioclase (35-40\%), quartz (25-35\%), potassium feldspar (20-25\%), and biotite ( 10\%) (Fig. 11). Hornblende is absent in the field area. Petrographic analysis reveals lowtemperature recrystallization of quartz grains. Plagioclase crystals range in length from 0.25 to $1 \mathrm{~mm}$, and average $0.5 \mathrm{~mm}$.

\section{Yosemite Creek Granodiorite}

The 97 Ma (Burgess et al., 2009) Yosemite Creek Granodiorite is a texturally variable granodiorite to tonalite that locally intrudes the Taft Granite as sheets and irregularly shaped masses in several parts of the study area. Johnson (2013) recognized five subunits within the Yosemite Creek Granodiorite. At least three subunits, similar to those described by Johnson (2013), have been observed in the study area, including a medium-grained granodiorite, a porphyritic granodiorite, and a tonalitic unit (Table 1). In addition, several relatively mafic bodies intrude the Taft Granite in the western part of the study area and may be related to the Yosemite Creek Granodiorite. 


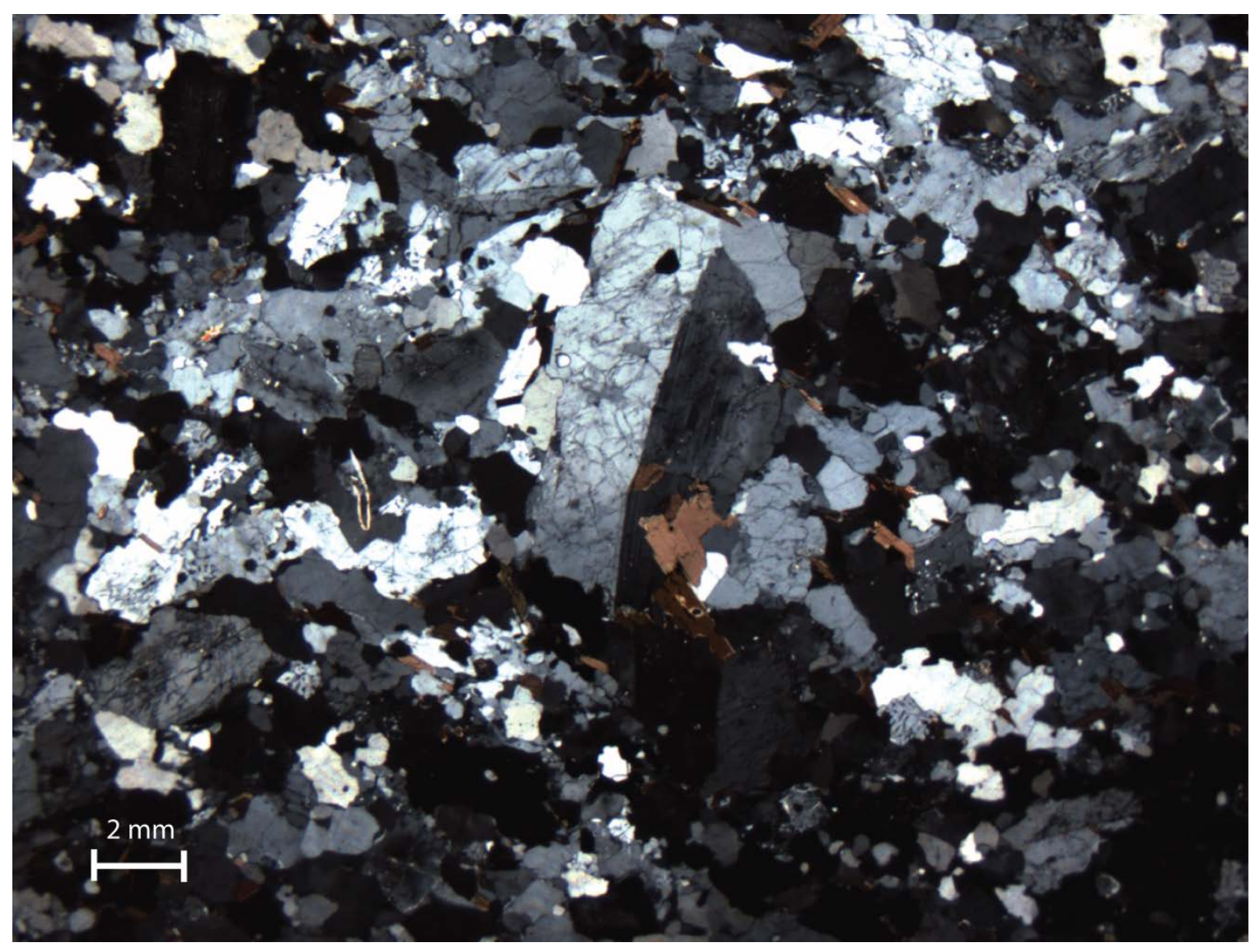

Figure 11. Photomicrograph (cross-polars) of porphyritic Tuolumne Peak granodiorite. Note large potassium feldspar phenocryst in center. 


\section{Medium-grained Yosemite Creek Granodiorite}

The medium-grained Yosemite Creek Granodiorite intrudes the Taft Granite in the southernmost portion of the study area as a $\sim 0.25-0.5 \mathrm{~km}$-wide sheet with several offshoots extending several hundred meters into the granite and the Tuolumne Peak granodiorite. This unit is generally equigranular, dominantly composed of plagioclase ( 45\%), quartz ( 30\%), biotite ( 12\%), and potassium feldspar ( 10\%), and has a color index of $\sim 12$ (Fig. 12). Plagioclase varies from $0.5-4 \mathrm{~mm}$, and averages $2 \mathrm{~mm}$ in length. Normal zoning is common and $\sim 10 \%$ of the grains are myrmekitic. Bent grains and deformation twins are common and grain boundaries typically have a jagged appearance. Quartz varies in length from $0.25-3 \mathrm{~mm}$, and averages $2 \mathrm{~mm}$. Checkerboard subgrains are developed in some samples. Grain boundaries have a jigsaw-puzzle-like shape where recrystallization is most prevalent, indicating grain boundary migration. Potassium feldspar varies in length from 1-3 mm, averaging $1 \mathrm{~mm}$. Carlsbad twins are abundant and seritization is ubiquitous. Biotite varies between 0.25 and $2 \mathrm{~mm}$ in length, and averages $0.5 \mathrm{~mm}$. Chloritization is common, affecting up to $40 \%$ of the grains. Biotite is typically bent around quartz and plagioclase grains. Aligned biotite almost exclusively defines the weak magmatic foliation. Secondary muscovite makes up $\sim 3 \%$ of the rock and apatite, zircon, and sphene occur as accessories.

\section{Porphyritic Yosemite Creek Granodiorite}

The porphyritic phase of the Yosemite Creek Granodiorite intrudes the Double Rock Granodiorite and Taft Granite in the westernmost portion of the study area as long 


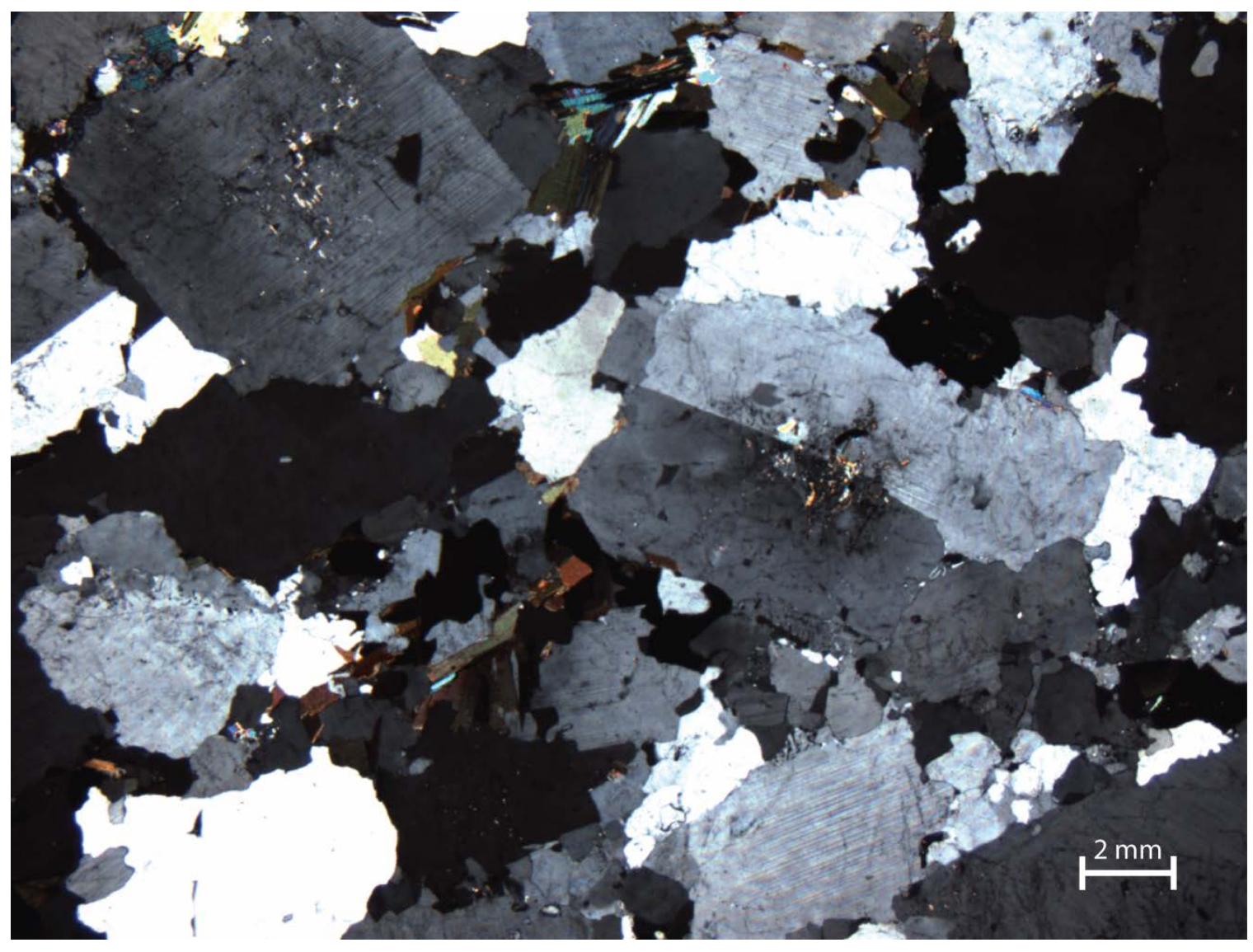

Figure 12. Photomicrograph (cross-polars) of medium-grained Yosemite Creek Granodiorite. Note jagged grain boundaries. 
narrow sheets, which trend northward into a large, oval-shaped mass (Plate 1). The granodiorite is dominantly composed of plagioclase ( 45\%), quartz ( $30 \%)$, biotite ( 15\%), and potassium feldspar ( 10\%) (Fig. 13). The rock has a color index of 15 and is characterized by euhedral, $10 \mathrm{~mm}$-long plagioclase phenocrysts. Plagioclase varies in length from 1-10 mm, averaging $5 \mathrm{~mm}$. Polysynthetic and simple twins are common. Normal zoning is prevalent, and myrmekitic texture is present in up to $5 \%$ of grains. Plagioclase locally encloses biotite. Quartz is $0.5-2 \mathrm{~mm}$ in length, and averages 1 mm. Checkerboard subgrains and bulging recrystallization are common. Potassium feldspar is typically coarse-grained and 2 to $10 \mathrm{~mm}$ long, with an average grain size of 4 mm. Simple twins and scotch-plaid twinning are common throughout. Perthitic texture and seritization are also extensive. Potassium feldspar grains locally enclose quartz, plagioclase, and biotite. Biotite makes up 15\% of the rock, and is typically fine-grained, with an average length of $0.25 \mathrm{~mm}$. Up to $50 \%$ of the grains are chloritized. Zircon, sphene, and secondary epidote occur as accessories. Magmatic foliation is defined by aligned biotite and is highly variable in intensity.

\section{Tonalitic Yosemite Creek Unit}

Several small bodies of tonalite intrude the westernmost exposures of the Yosemite Creek Granodiorite. Intrusive relationships described below suggest that these bodies are roughly co-magmatic with the granodiorite. The tonalite is dominantly composed of plagioclase ( 45\%), quartz ( 20\%), biotite ( 20\%), and hornblende ( 15\%). It is medium-grained, generally equigranular, and has a color index of $\sim 35$. 


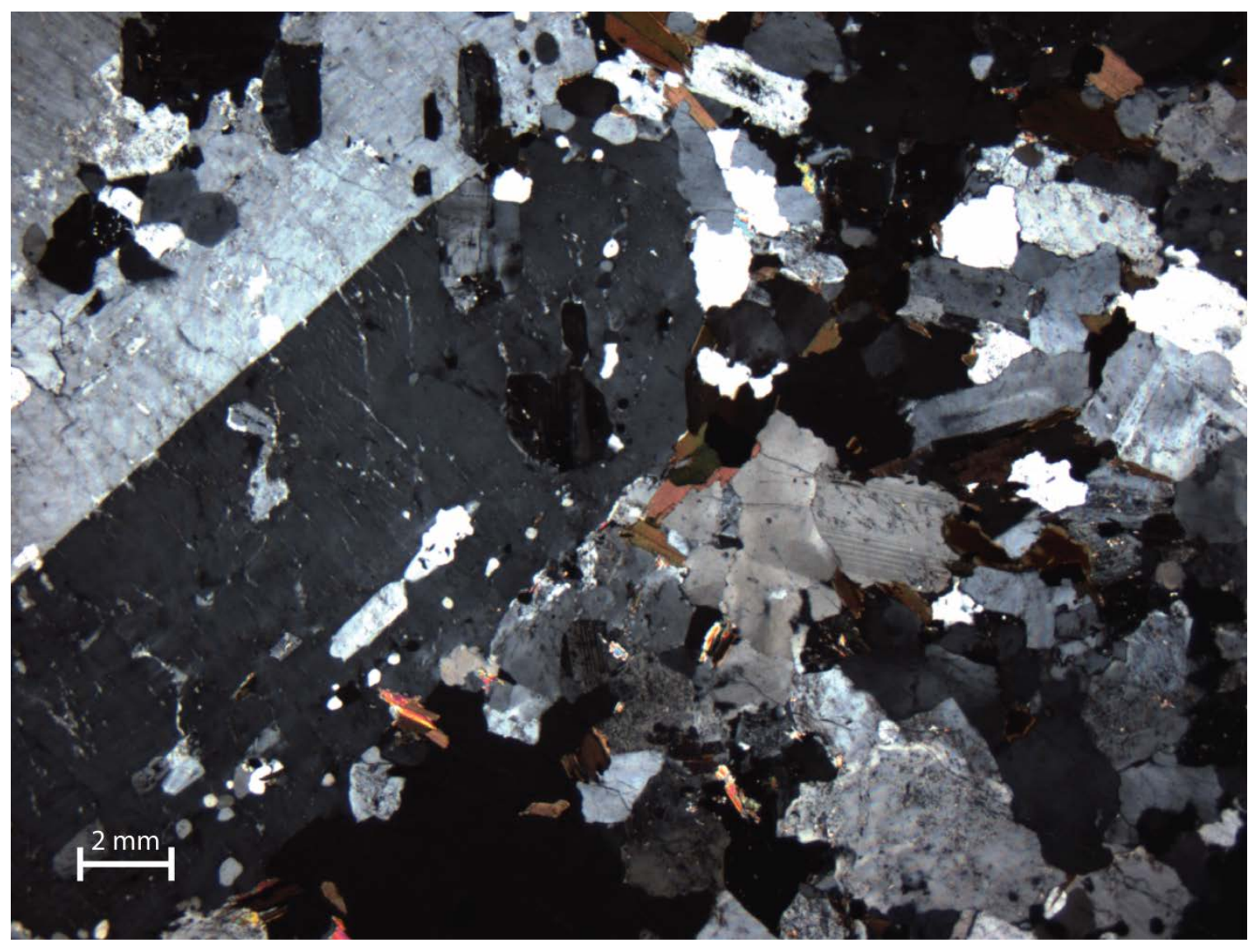

Figure 13. Photomicrograph (cross-polars) of porphyritic Yosemite Creek Granodiorite. Note twinning, zoning, and inclusions of quartz and plagioclase in potassium feldspar phenocryst. 
Subhedral plagioclase is 0.5 to $2 \mathrm{~mm}$ in length, and averages $1 \mathrm{~mm}$. Plagioclase grains locally enclose biotite and hornblende. Polysynthetic twins, deformation twins and normal zoning are common. Quartz grains are $0.25-1 \mathrm{~mm}$ wide, averaging $0.5 \mathrm{~mm}$. Subgrains are well-developed, locally displaying a checkerboard pattern. Biotite is between 0.25 and $1 \mathrm{~mm}$ long, with an average length of $0.5 \mathrm{~mm}$, and is replaced by minor chlorite. Hornblende is $0.25-0.5 \mathrm{~mm}$ in length, averaging $0.3 \mathrm{~mm}$. Sphene is ubiquitous and makes up to $1 \%$ of the tonalite. Apatite is present in trace amounts.

Several additional bodies ( 20 by $30 \mathrm{~m}$ ) with a high color index are exposed in the western half of the field area, are enclosed entirely within the Taft Granite, and locally exhibit evidence for minor mingling along contacts with the granite. The westernmost mafic body occurs near the contact of the Taft Granite with the Yosemite Creek Granodiorite and is similar in some respects to the tonalitic phase of the Yosemite Creek Granodiorite. This mafic body has sharp, angular contacts with the Taft Granite and encloses meter-scale blocks of the granite. These relationships indicate that the rock types had very different rheologies when the mafic body intruded or that the mafic magma introduced enough heat to remobilize the granite along the contact.

\section{Glen Aulin Tonalite}

The 93.1 Ma (Coleman et al, 2004) Glen Aulin Tonalite is the oldest unit of the 85-94 Ma Tuolumne Intrusive Suite, and intrudes metasedimentary host rock and plutonic rocks of the Yosemite Valley Intrusive Suite in the eastern part of the study area. 
The composition of the unit ranges from a tonalite, in the west, to a granodiorite in the east (Bateman et al., 1983). In the study area, the unit is a medium-grained tonalite to granodiorite, with a well-developed foliation best defined by aligned biotite grains, and a color index of $\sim 20$, higher than that of most older plutonic rocks in the study area.

\section{STRUCTURE}

Solid-state and magmatic structures are common in many of the units in the study area, whereas measurable lineation is mostly confined to the eastern part of the study area. Planar features typically dip steeply and strike variably. A northwest-striking magmatic foliation in the eastern part of the study area is coincident with orientations observed elsewhere in the Sierran batholith in rocks of similar age (Zak and Paterson, 2005; McFarlan, 2007).

\section{Magmatic Foliation}

Magmatic foliation in the study area is dominantly defined by aligned biotite and hornblende grains, and locally by feldspar phenocrysts. Magmatic foliation was measured in all igneous units and is best developed in the granodiorites of the eastern part of the study area and the westernmost body of the Yosemite Creek Granodiorite (Fig. 14). Foliation within the Taft Granite is typically faint to unmeasurable. 


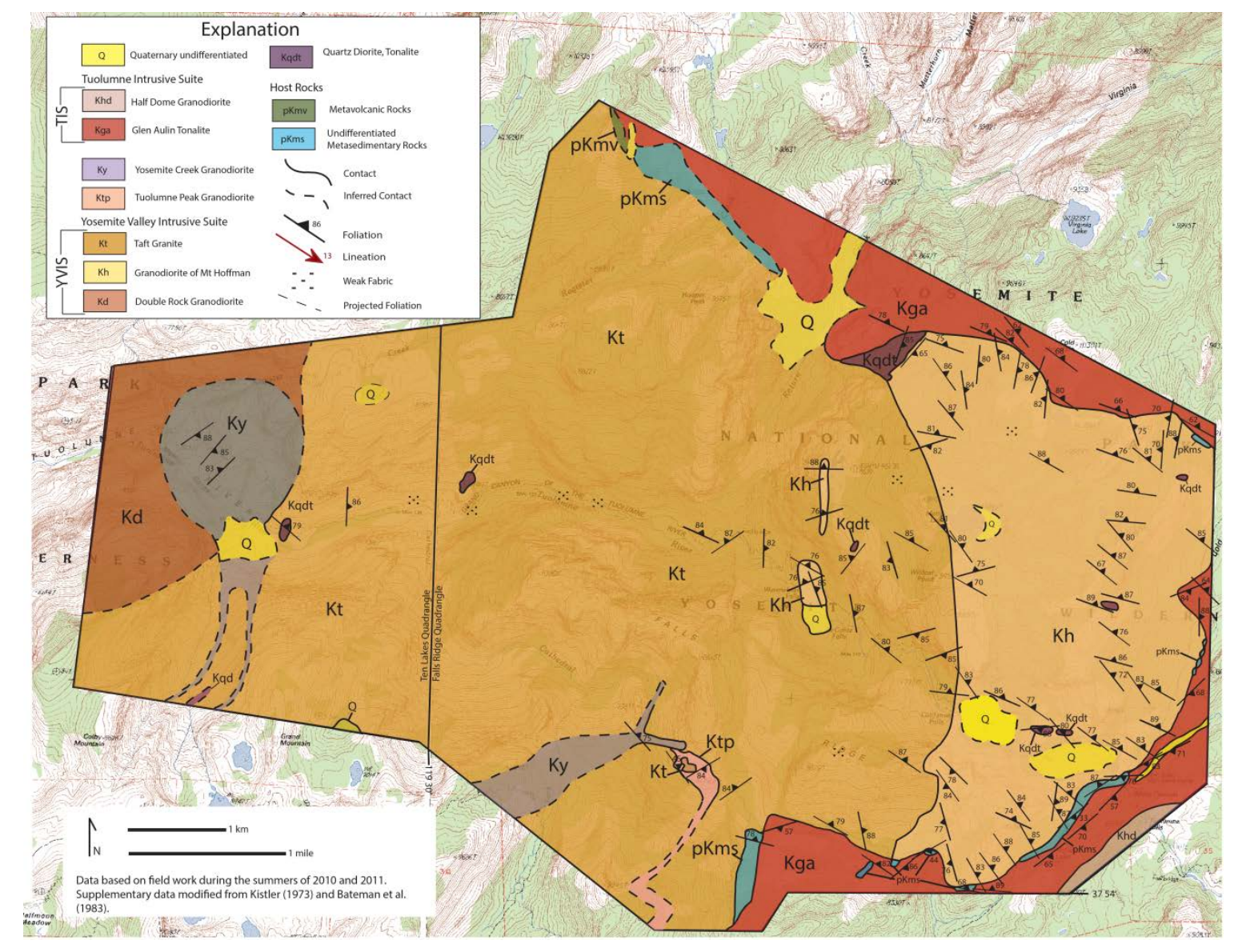

Figure 14. Simplified geologic map emphasizing magmatic foliations in study area. Lineations removed for clarity. 
Magmatic foliation varies in orientation across much of the study area, but in places defines domains with consistent patterns that extend for several kilometers. Foliation commonly occurs at a high angle to contacts between units of the Yosemite Valley Suite, as well as to contacts between this suite and the younger Tuolumne Intrusive Suite.

A northwest- to west-northwest-striking, steeply-dipping foliation dominates parts of the Mt. Hoffman granodiorite in the southern and easternmost areas. Foliation has a more west-northwest strike in the center of the granodiorite (Fig. 14). Along the margin of the Mt. Hoffman granodiorite foliation locally bends into parallelism with Tuolumne Intrusive Suite contact within several meters of the contact, as well illustrated in the northern margin of the granodiorite (Fig. 14). Foliation in the granodiorite directly adjacent to the contact with the Taft Granite adopts a more variable pattern, displaying the northwesterly strike seen elsewhere, as well as a west-northwest and east-west strike in several locations.

Magmatic foliation within the Taft Granite varies significantly in orientation. In places, it displays the northwest strike measured commonly in the Mt. Hoffman granodiorite, whereas elsewhere foliation displays no discernible pattern. Foliation is commonly at a high angle to the eastern contact with the older Mt. Hoffman granodiorite. Foliation intensity decreases west of this contact, becoming undetectable towards the center of the pluton. The apparent absence of foliation in the Taft Granite has also been noted by previous authors (Bateman et al., 1983) and may be attributed to the low color index of the Taft Granite and weak strain recorded in this unit. 
A northeast-striking, steeply dipping foliation dominates the large body of Yosemite Creek Granodiorite in the westernmost part of the study area as in the granodiorite directly to the south (Johnson, 2013). Foliation in the Yosemite Creek Granodiorite in the southern part of the study area strikes northwest, dips steeply, and is at a high angle to contacts with older units.

The Tuolumne Peak granodiorite, which is exposed in the southern part of the study area, displays both northwest- and northeast-striking foliation (Fig. 14). Dip is steep in both orientations. Strike is generally at a high angle to contacts, but locally is parallel to the margin.

Rocks of the younger Tuolumne Intrusive Suite commonly have margin-parallel magmatic foliation. Foliation mimics the contact between the Yosemite Valley Intrusive Suite and Tuolumne Intrusive Suite, as it swings through the nearly $90^{\circ}$ bends of the salient in the eastern portion of the study area (Fig. 14).

\section{Magmatic Lineation}

Magmatic lineation is weak throughout the majority of the study area, but several small areas display a relatively well-defined fabric. Where measureable, lineation in plutonic rocks is typically defined by aligned biotite. Lineation in metasedimentary rocks is variably defined by muscovite, biotite, and locally sillimanite. Measured lineation is restricted to the eastern half of the study area in the granodiorite of Mt. Hoffman and the metasedimentary rocks between the Yosemite Valley Intrusive Suite and Tuolumne 
Intrusive Suite. The lack of measurable lineation in the western portion of the study area may be attributable to lower-color-index rocks lacking the necessary contrast to display lineation in outcrops.

Lineation is variably oriented, but a north to northwest trend dominates (Fig. 15) and plunges in the plutonic rocks vary from moderate $\left(40^{\circ}\right)$ to steep (up to $73^{\circ}$ ), and average $59^{\circ}$. Lineations in the Mt. Hoffman granodiorite were measured near contacts, and the trends are generally at a high angle to contacts between Yosemite Valley rocks and the Tuolumne Intrusive Suite.

\section{Contacts}

Contacts throughout the study area are typically sharp and dip steeply. Strike of contacts is highly variable (Plate 1). Mingling is prevalent along contacts between some units, but gradational contacts are not observed in the study area.

\section{Metasedimentary Rock Contacts}

Elongate bodies of metasedimentary rocks, ranging from $10 \mathrm{~m}$ to $1.5 \mathrm{~km}$ in length, are found along the contact between the Yosemite Valley and Tuolumne Intrusive Suites, particularly in the southeastern and northernmost parts of the study area. The orientation of contacts defines the $90^{\circ}$ bends of the large salient in the eastern part of the study area. 


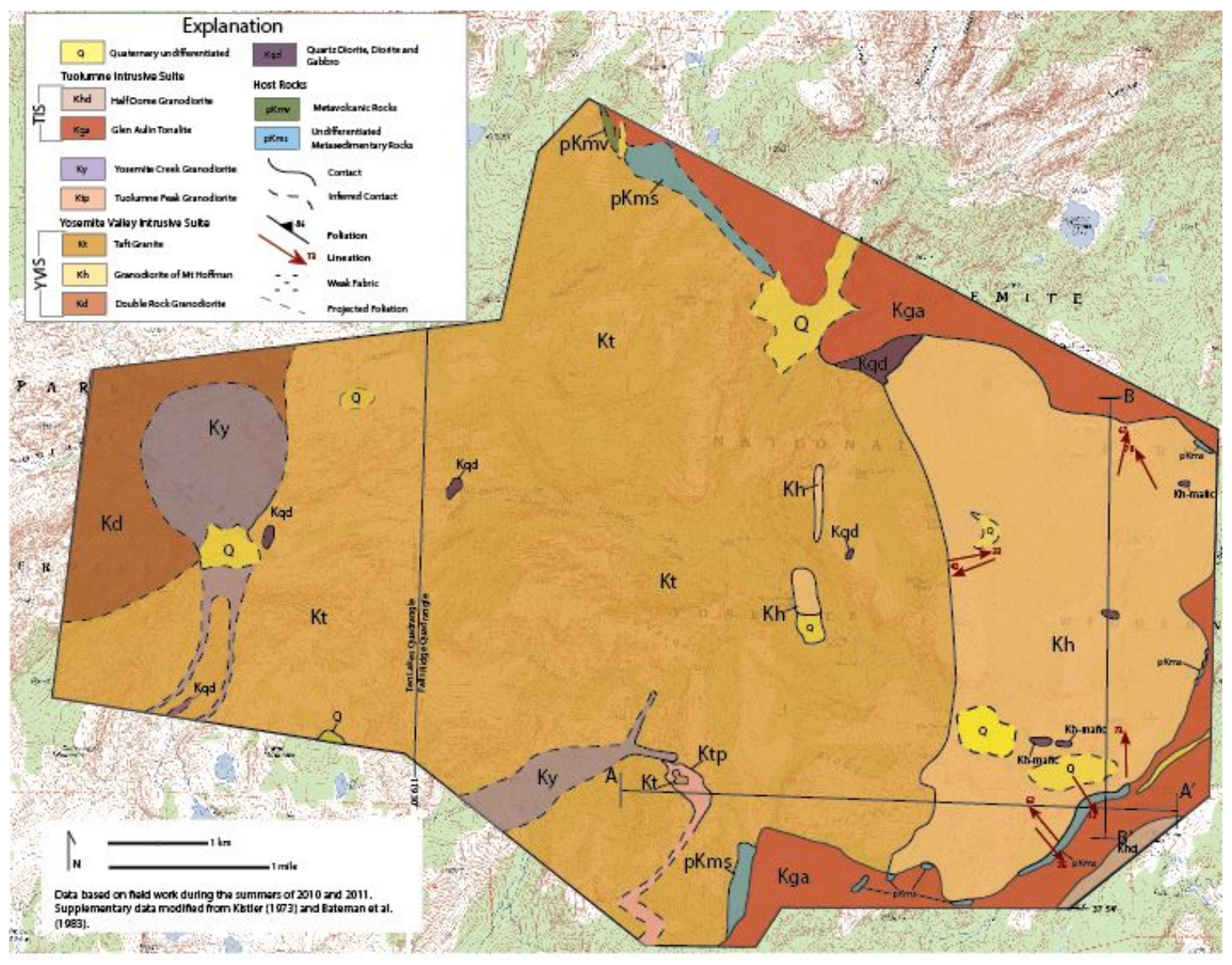

Figure 15. Geologic map emphasizing lineations in study area. Foliations removed for clarity. 
Metasedimentary rocks are in contact with the Mt. Hoffman granodiorite, Taft Granite, and Glen Aulin Tonalite. Contacts with the plutonic rocks are sharp, typically stepped, and dip moderately to steeply. Plutonic units intrude the metasedimentary pendants, although typically as small volumes. Metasedimentary xenoliths, ranging from 3 by $4 \mathrm{~cm}$ to 30 by $40 \mathrm{~cm}$, also occur in all plutonic units in contact with the metasedimentary rock.

\section{Yosemite Valley-Tuolumne Intrusive Suite Contacts}

Approximately $18 \mathrm{~km}$ of the contact between the Yosemite Valley Intrusive Suite and Tuolumne Intrusive Suite is exposed in the study area. Metasedimentary host rocks are exposed along $\sim 6 \mathrm{~km}$ of the contact. Where the two suites are in direct contact, the Glen Aulin Tonalite intrudes the Taft Granite and the Mt. Hoffman granodiorite of the Yosemite Valley Suite.

The contact between the Glen Aulin Tonalite and Mt. Hoffman granodiorite ranges from sharp to slightly diffuse across small areas. In general, the contact is arcuate in map-view (Plate 1) and dips steeply. Enclave swarms and narrow zones, 1-3-m wide, of mingling are common across the contact. In some locations, 0.5-1-m-wide sheets and small, discrete bodies and fingers of Glen Aulin Tonalite (ranging from $0.5 \mathrm{~cm}$ to $2 \mathrm{~m}$ in thickness) intrude the Mt. Hoffman granodiorite, typically extending only a few meters into the granodiorite. In the northern part of the study area, foliation in the Mt. Hoffman granodiorite is deflected into parallelism with the contact within 1-2 $\mathrm{m}$ of the contact. 
Approximately one meter of mingling occurs between the tonalite and granodiorite at this location and mafic tubes and enclave swarms are abundant within the granodiorite.

The contact between the Glen Aulin Tonalite and Taft Granite is generally sharp and dips steeply. Enclaves and dikes, mainly of a dioritic composition, are common in the tonalite within several meters of the contact. In two locations, the contact is stepped, displaying nearly $90^{\circ}$ bends. The larger bend occurs in the southern part of the study area (Plate 1) where the contact swings from a nearly east-west to north-south trend, a pattern that continues for several kilometers to the south of the study area (Bateman et al., 1983). A much smaller step of $\sim 3 \mathrm{~m}$ coincides with a solid-state shear zone, which offsets the contact. The tonalite intrudes the Taft Granite in several locations as small, discrete, 1-3m-wide bodies that are never more than a few meters from the main contact. The contact between these bodies of tonalite and granite are slightly diffuse, suggesting that remelting of the granite occurred.

\section{Taft Granite-Mt. Hoffman Granodiorite Contact}

The Taft Granite-Mt. Hoffman granodiorite contact generally trends north-south, is broadly arcuate in the north, and becomes more sinuous and locally stepped in the southern part of the field area. The contact is typically sharp, but there are segments, particularly in the central part of the study area, where a discrete contact is absent. In these locations, discerning between units is complicated by compositional similarities. Pegmatitic dikes and solid state shear zones are found locally on both sides of the contact. 


\section{Tuolumne Peak Granodiorite Contacts}

The Tuolumne Peak granodiorite intrudes the Taft Granite in the southern portion of the field area with sharp, steeply dipping contacts. Angular blocks of Taft Granite, ranging from $0.5-10 \mathrm{~m}$ in length, are incorporated in the granodiorite within several meters of the contact. Several solid-state shear zones occur near the contact in the granodiorite.

\section{Yosemite Creek Granodiorite Contacts}

The Yosemite Creek Granodiorite intrudes the Taft Granite in the southern and western portions of the field area, and also intrudes the Tuolumne Peak granodiorite. All contacts are sharp and dip steeply. The Yosemite Creek Granodiorite and Taft Granite are locally mingled in the western portion of the study area where the granodiorite appears to have partially remobilized some of the granite within $1 \mathrm{~m}$ of the contact.

\section{Pegmatite and Aplite Dikes}

Pegmatite and aplite dikes are confined to the Mt. Hoffman granodiorite and Glen Aulin Tonalite. These dikes typically appear to be derived from local melt as they rarely extend for more than a few meters. Aplitic dikes generally contain a pegmatitic core.

Pegmatite dikes in the Mt. Hoffman granodiorite typically strike north-northeast and dip moderately to both the west-northwest and east-southeast. Dikes vary in width between $0.15 \mathrm{~m}$ and $1 \mathrm{~m}$ and are observed to extend for 3-4 $\mathrm{m}$ with the full extent 
commonly obscured by vegetation. In at least one location, a pegmatite dike is parallel to magmatic foliation. Aplitic dikes in the Mt. Hoffman granodiorite are generally subparallel to foliation and tend to dip steeply. They have an average width of $\sim 0.15 \mathrm{~m}$. Sub-horizontal pegmatitic dikes are common in the Glen Aulin Tonalite and display a random strike.

\section{Ductile Shear Zones}

Scattered ductile shear zones are confined to the eastern portion of the study area, dominantly in the Mt. Hoffman granodiorite. The shear zones are generally $20-50 \mathrm{~cm}$ in width, and extend for 0.5-5 m. They are concentrated along contacts between units and at the boundaries of dikes, mafic bodies, and enclave swarms. Although the strike of shear zones is variable, east-west to east-northeast trends are common in the Mt. Hoffman granodiorite (Fig. 16). In the Taft Granite, no dominant strike is evident. Measured shear zones dip between 56 and $90^{\circ}$. Well-developed S-C fabric, dominantly defined by biotite, indicates a reverse sense of shear. Several shear zones that cut the porphyritic phase of the Mt. Hoffman granodiorite contain $\sigma$-type porphyroclasts of plagioclase that also record a reverse sense of shear (Fig. 17).

The greatest number of shear zones was measured in the northern-most section of the Mt. Hoffman granodiorite, within $1 \mathrm{~km}$ of the contact with the Tuolumne Intrusive Suite. In at least one location, shear zones bend into parallelism with the Tuolumne contact within several meters of this boundary. 


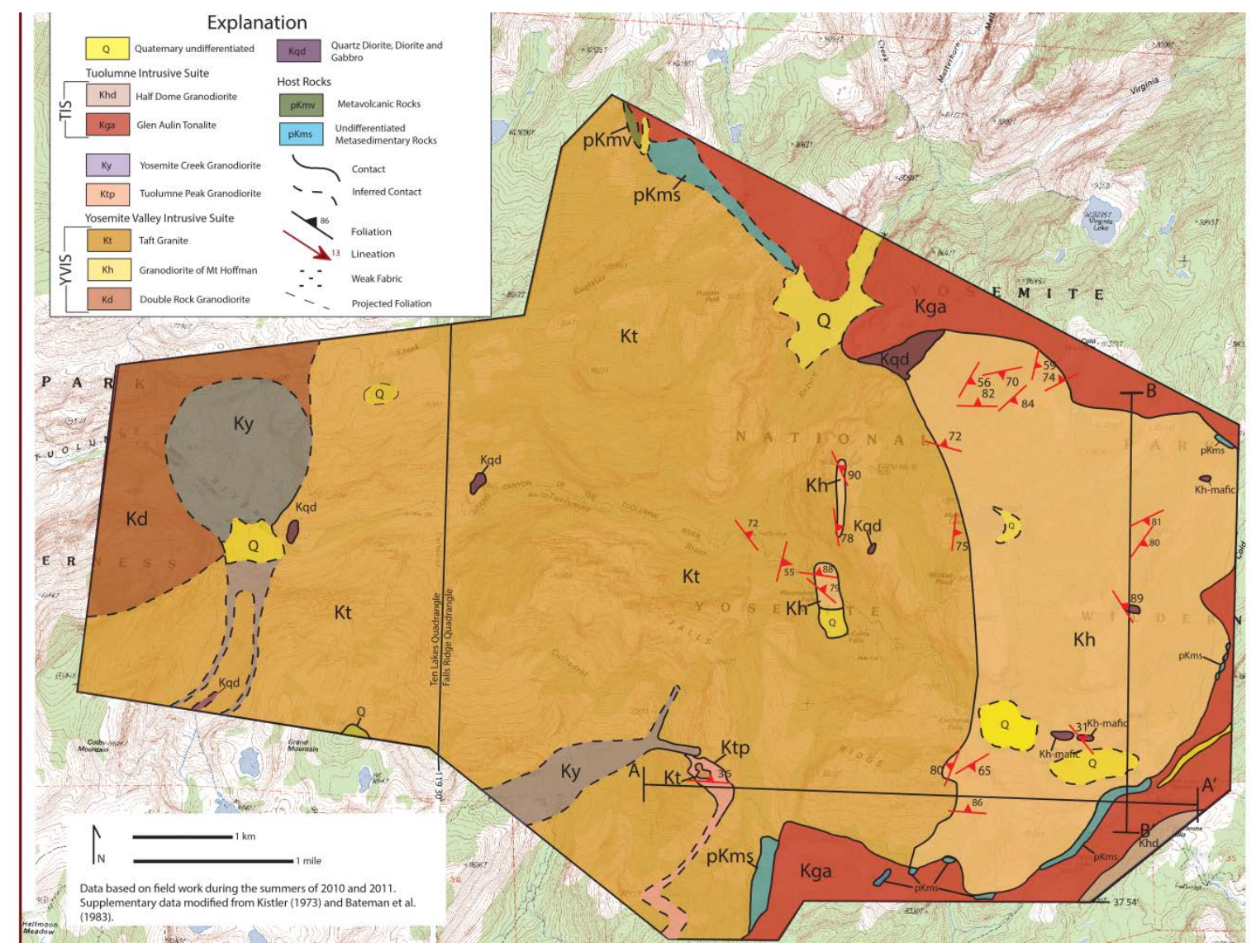

Figure 16. Geologic map emphasizing shear zones in study area. Shear zones depicted by red foliation pattern. Foliations and lineations removed for clarity. 


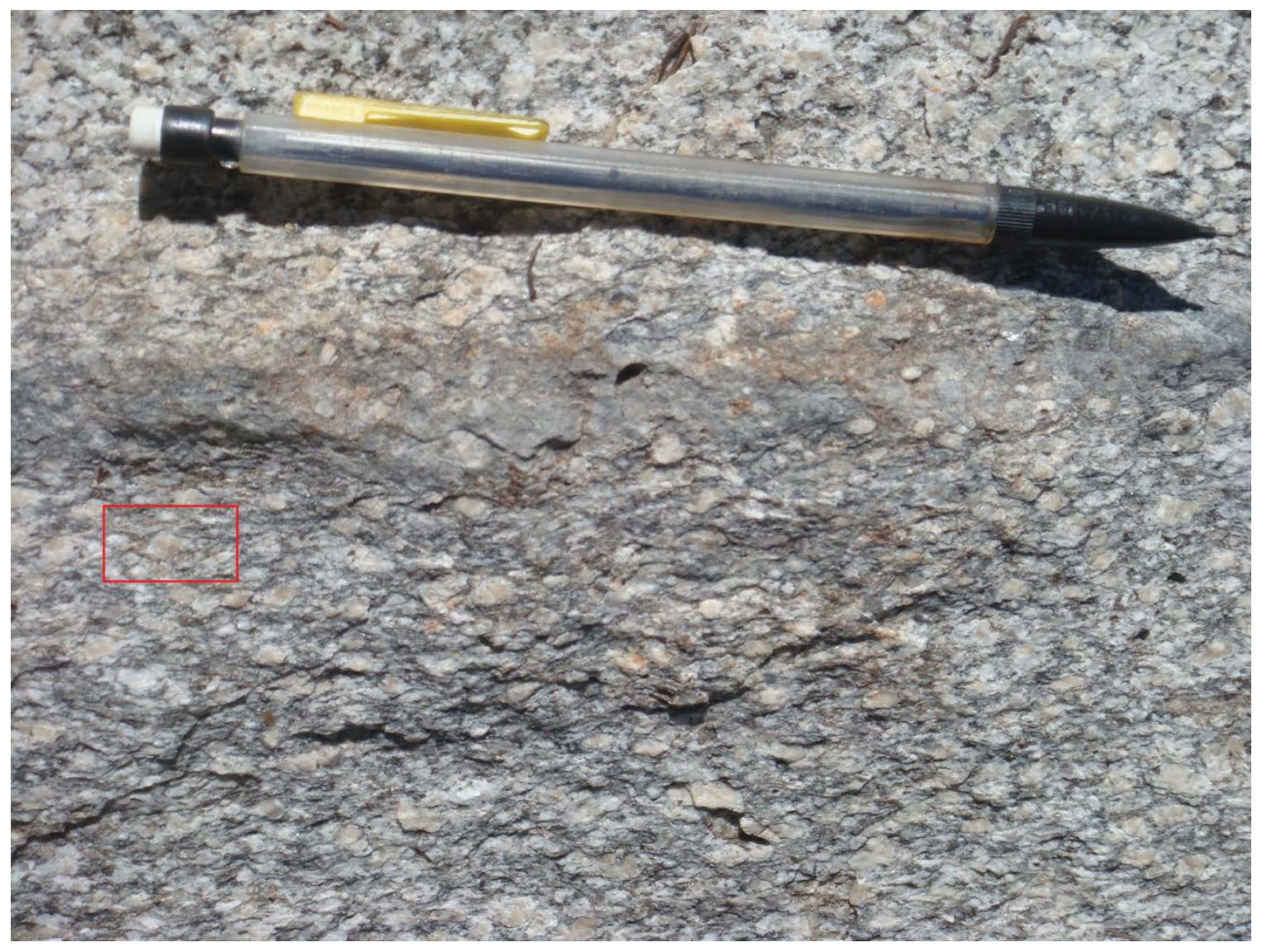

Figure 17. Protomylonitic Mt. Hoffman granodiorite in shear zone. Note asymmetric porphyroclasts (in red box) indicating reverse (top-to-the-right) sense of shear. Porphyritic phase of the granodiorite. 
The few shear zones measured in the Taft Granite are confined to areas adjacent to bodies of Mt. Hoffman granodiorite enclosed by the granite (Fig. 16). No ductile shear zones were recognized in the Yosemite Creek Granodiorite or Tuolumne Peak granodiorite.

Petrographic analysis of rocks from shear zones indicates extensive solid-state deformation of quartz and recrystallization of plagioclase and potassium feldspar. Quartz grains in and adjacent to shear zones display a variety of microstructures, including chessboard subgrains, a likely indicator of high-temperature strain (Kruhl, 1996). Grain-size reduction of quartz as the result of complete recrystallization to polygonal mosaics suggests that deformation in shear zones occurred at temperatures of $>300^{\circ} \mathrm{C}$ (Hirth and Tullis, 1992). Irregularly shaped grain boundaries due to grain boundary migration of quartz further indicate that deformation temperatures exceeded $500^{\circ} \mathrm{C}$. Relict plagioclase and potassium feldspar crystals surrounded by polygonal mosaics of the same phases also support medium- to high-temperature deformation. Recrystallization of hornblende is suggested by grain-size reduction, further indicating medium- to high-temperature deformation.

\section{Microstructures in Plutonic Rocks Outside of Ductile Shear Zones}

Solid-state deformation of plutonic rocks in the study area outside of ductile shear zones occurred at a range of temperatures, as indicated by microstructures mainly seen in 
quartz, plagioclase, and orthoclase. Although solid-state microstructures occur in most samples, the overall deformation of plutonic rocks suggests relatively low strain.

Quartz in the Mt. Hoffman granodiorite records dislocation creep. Evidence includes chessboard subgrains and variable recrystallization of quartz marked by irregularly shaped or planar grain boundaries and polygonal mosaics. Some samples contain orthoclase grains with rims of fine-grained orthoclase, and are interpreted to record deformation at moderate to high temperatures $\left(\geq 450^{\circ} \mathrm{C}\right)$ (Tullis and Yund, 1985). The body of Mt. Hoffman granodiorite enclosed within the Taft Granite $~ 1 \mathrm{~km}$ from the main contact between these units contains two distinct grain sizes. In an overall coarsegrained rock, there are fine-grained, recrystallized areas (up to several centimeters wide), marked by grain-size reduction of quartz. These domains are interpreted to record moderate- to high-temperature dynamic recrystallization. Tonalitic bodies within the Mt. Hoffman granodiorite contain quartz grains with chessboard subgrains and the rocks have a well-developed mosaic texture also suggesting at least moderately high temperatures of deformation.

Quartz grains in the Taft Granite display undulose extinction and have minor irregularly shaped grain boundaries, which imply dislocation processes at relatively low temperatures $\left(\sim 300-400^{\circ} \mathrm{C}\right)$ (e.g., Vernon, 2004). The relatively mafic bodies associated with the Taft Granite also contain mosaics of quartz and grains with chessboard subgrains indicating moderately high deformation temperatures.

Quartz in the Yosemite Creek Granodiorite and Tuolumne Peak granodiorite has chessboard subgrains and irregularly shaped grain boundaries indicative of grain 
boundary migration. These microstructures also support medium- to high-temperature deformation for these rocks.

\section{Structure in Metasedimentary Rocks}

The metasedimentary bodies separating the Yosemite Valley Intrusive Suite and Tuolumne Intrusive Suite have a long axis parallel to contacts (Plate 1). Strike of foliation in the metasedimentary rocks is typically parallel to those contacts. Foliation dips moderately $\left(\sim 30-60^{\circ}\right)$ to the southeast and northwest.

Lineation is scarce, but generally trends to the northwest. It is defined by muscovite, biotite, and locally sillimanite. The highest measured concentration of lineations occurs in the pendant at McGee Lake (Fig. 15). All lineations in this body trend to the northwest or southeast, at a high angle to the contacts with the neighboring intrusive suites, and have relatively shallow plunges, ranging from $13-40^{\circ}$.

Chaotic folding and boudinage occur where the metasedimentary rocks separate the Glen Aulin Tonalite from the Taft Granite and Mt. Hoffman granodiorite in the southernmost part of the study area (Plate 1). Folds are generally tight to isoclinal. Orientations of fold hinge lines in this area are highly variable, which probably reflects multiple stages of deformation. Emplacement of one or some combination of the three surrounding plutons may have contributed an increment of strain that potentially overprinted one or more regional deformational events, making interpretation of the history exceedingly difficult. 
Open microfolds, defined by polygonal mosaics of muscovite, are evident in several samples from different locations in the study area. Hinge lines are at a moderate angle to lineation.

The metasedimentary body at McGee Lake (Plate 1) displays two foliations, one dominant and parallel to the contact between the Yosemite Valley Intrusive Suite and Tuolumne Intrusive Suite, and a second fabric at $\sim 30^{\circ}$ to the dominant foliation. Both foliations are defined by alignment of muscovite. As elsewhere, the two fabrics may represent deformation during emplacement of one or both surrounding plutons, and/or regional deformation.

\section{DISCUSSION}

As noted in the introduction, plutons provide excellent opportunities to study the deeper levels of ancient magmatic systems, as they commonly record evidence for the construction, emplacement, and post-emplacement magmatic processes which cannot be easily determined from observations of modern volcanic systems. In the following

section, I discuss possible models for construction of the plutons within the study area, and address how tectonic strains may be recorded in the plutons and metasedimentary host rocks. 


\section{Construction of Plutons}

Consensus now favors construction of plutons via multiple magmatic increments, but debate still lingers regarding the number, size, and timing of increments of magma, and whether sizable magma chambers develop (e.g., Paterson and Vernon, 1995; Wiebe and Collins, 1998; Miller and Paterson, 2001; Glazner et al., 2004; Zak and Paterson, 2005; Miller et al., 2011; Paterson et al., 2011). The thermal limitations of magmatic systems serve as a point of contention regarding construction of sizable magma chambers. Some authors argue that if magma chambers form, they are likely small and short-lived (e.g., Glazner et al., 2004), whereas others have found evidence for sizable (100’s km³) magma bodies that persisted for $\sim 100,000$ years (Matzel et al., 2006). The duration of construction of plutons varies within the modern literature, ranging from tens of thousands of years for small plutons to several million years for large ones (e.g., Glazner et al., 2004). A number of studies have suggested that field observation of plutonic features, such as schlieren, enclaves, tubes, dikes, and internal contacts, may aid in interpretation of construction processes, increment size, and magma chamber development (e.g., Paterson et al., 1998; Zak and Paterson, 2005; Solgadi and Sawyer, 2008). Interpretation of magmatic features observed in the study area, with the aid of models proposed by previous workers, provides new insight into the current understanding of magmatic processes in the central Sierra Nevada batholith, and particularly in the Yosemite Valley Intrusive Suite. 


\section{Yosemite Valley Intrusive Suite}

Mt. Hoffman Granodiorite. The Mt. Hoffman granodiorite displays compositional and textural variations throughout the study area, and mafic enclaves, schlieren, and mafic bodies are scattered throughout the unit. Clear internal contacts are absent and thus distinct subunits are not readily apparent. The lack of internal contacts, coupled with the textural and compositional heterogeneity, may reflect construction of the unit via increments that interacted but did not homogenously mix. The presence of schlieren supports this interpretation as they likely formed in a dynamic magmatic system due to flow in a crystal-rich body of magma that was capable of intermingling (Barriere, 1977; Solgadi and Sawyer, 2008).

Three reasonably sizable, discreet, but petrographically similar bodies of tonalite are enclosed within the Mt. Hoffman granodiorite and the similarities among these bodies suggest derivation from the same or a similar source (see chapter on ROCK UNITS). These bodies exhibit variable contact relationships with the Mt. Hoffman granodiorite. The mafic body just north of the Tuolumne River (Plate 1) has a sharp, angular contact with the granodiorite, and incorporates several blocks of the granodiorite. Two mafic bodies $\sim 1 \mathrm{~km}$ to the north display both sharp and gradational contacts with the surrounding granodiorite. The larger body extends for $\sim 10 \mathrm{~m}$ as a cohesive mass before transitioning into a disaggregated enclave swarm covering an area of roughly $15 \mathrm{~m}$ x 15 m. The other body displays sharp and gradational contacts with the host. These relationships indicate complex rheology and that felsic and mafic magmas were in part co-magmatic. 
In contrast, the tonalitic body north of the Tuolumne River (Plate 1) is in sharp contact with surrounding rock and has incorporated several angular $\sim 1$ x $2 \mathrm{~m}$ blocks of the granodiorite (Fig. 6). The body was previously mapped as part of the tonalite of Glen Aulin of the Tuolumne Intrusive Suite (Bateman et al., 1983) and is $~ 1 \mathrm{~km}$ from this suite. The high color index ( 20-25) and well-developed foliation supports this interpretation. In addition, the sharp contacts and xenoliths suggest a stark rheological contrast. However, clinopyroxene cores in hornblende and biotite suggest that the tonalite is temporally related to the mafic bodies associated with the Mt. Hoffman granodiorite.

One of two interpretations seems likely: 1) this mafic intrusion represents a magma that is temporally related to the tonalite of Glen Aulin, and is considerably younger than the granodiorite of Mt. Hoffman; or 2) this intrusion shares a similar source, but is at least slightly younger than the other mafic intrusions that display a clear comagmatic relationship with the Mt. Hoffman granodiorite. I favor the latter explanation on the basis of the petrographic similarities between the different mafic bodies. Overall, the rheological contrast between the individual mafic bodies and their hosts suggests that mafic magmas intruded while the granodiorite was in various stages of solidification.

The mafic bodies may be comparable petrologically to the "diorite of Rockslides" (Ratajeski et al., 2001), which is also a coarse-grained, equigranular, hornblende-biotitequartz diorite to tonalite that contains rare clinopyroxene as relict cores within hornblende. Ratajeski et al. (2001) interpreted the diorite to have intruded the El Capitan Granite as the granite was crystallizing, and that the dioritic material disaggregated to 
form enclaves, enclave swarms, and mafic pods. This interpretation fits with field and petrographic observations of the mafic rocks in the Mt. Hoffman granodiorite, a unit which is similar and roughly coeval to the El Capitan Granite.

A texturally and mineralogically distinct variety of the Mt. Hoffman granodiorite was observed within several meters of the contact with the Tuolumne Intrusive Suite in several locations within the study area. This marginal subunit is distinguished from “typical” Mt. Hoffman granodiorite by a lower color index ( 5-7) and granitic composition. Several scenarios may account for this subunit.

In one model, this subunit is related to emplacement of the Tuolumne Intrusive Suite, where heat from intrusion was sufficient to partially melt the margin of the Mt. Hoffman granodiorite, producing a more silica-rich melt. Evidence for this interpretation would include mingling between the felsic rocks and the Tuolumne Suite tonalite, which is absent. Further arguing against this interpretation, a weak foliation in the felsic rocks strikes northwest, at a high angle to the contacts of the rocks and to foliation within the tonalite, but is coincident with the regional foliation measured elsewhere in the Mt. Hoffman granodiorite.

Alternatively, the marginal unit may represent a highly fractionated, residual melt that drained the last remnants of the magma reservoir associated with the Mt. Hoffman granodiorite. Contraction of the granodiorite upon cooling may have created space along the margin providing a structural weakness along which the magma intruded (Zak and Paterson, 2005). The concordance of the foliation to that seen elsewhere in the Mt. Hoffman granodiorite suggests that the "typical” Mt. Hoffman granodiorite and the 
marginal granite record the same increment of strain, perhaps suggesting that they were in the final stages of crystallization at the same time. Field evidence favors this observation. Finally, it is possible that the marginal granite is related to the Taft Granite. The low color index and weak foliation is compatible with observations made in the Taft Granite in the study area.

Taft Granite. Enclaves and schlieren are largely absent from the Taft Granite, an observation consistent with those made directly to the south of the study area (Johnson, 2013). Several map-scale, relatively mafic bodies are present in the study area, but are volumetrically small compared to the granite. Compositional and textural variations in the granite are generally gradational and internal contacts are absent. The homogeneity of the voluminous granite is consistent with the development of a large magma chamber or chambers capable of widespread mixing, but nearly identical magmas progressively derived from a similar source cannot be ruled out.

Tonalitic bodies within the Taft Granite (see chapter on ROCK UNITS) enclose xenoliths ranging in size from several centimeters to several meters (Fig. 8-9). Disaggregation and incorporation of xenoliths in the granite likely led to a rapid decrease in the temperature and mobility of the magma, thereby decreasing redistribution of host material (Glazner, 2007). Minor rotation of several xenoliths is evident by the difference in orientation of magmatic foliation between the main Taft Granite and the xenoliths. These relationships all suggest that the tonalite intruded and stoped the Taft Granite while the latter was solid. 
Relationships in the Taft Granite in the study area are unlike those observed between the granite and the North American mafic dike complex in Yosemite Valley. Ratajeski et al. (2001) described a leucocratic biotite-tonalite similar to that discussed above, but noted that field relationships suggest it is coeval with the Taft Granite. The Taft Granite in Yosemite Valley also contains a significant amount of enclaves, schlieren, and mafic bodies, characteristics generally lacking in the study area. If the tonalite in the field area is comparable to that of the dikes of the North American wall of El Capitan, two hypotheses may explain the contrasting field relationships. The Taft Granite in the study area is younger than that exposed in Yosemite Valley, or tonalitic magmas derived from the same, or a similar source intruded the Taft Granite over a substantial time period as the granite was in varying stages of crystallization. Geochronologic and geochemical data are necessary to better evaluate these hypotheses.

\section{Tuolumne Peak Granodiorite}

The volumetrically small Tuolumne Peak granodiorite sharply intrudes the Taft Granite in the southern portion of the study area as an $~ 20$ m wide sheet that apparently fed an irregularly shaped mass. Enclaves, schlieren, and mafic bodies were not observed. The small volume of this unit coupled with the absence of dynamic features suggests that a sizable magma chamber did not develop. The pluton may have been constructed via one or several small pulses of magma that intruded as sheets, occasionally pooling to form small bodies (Plate 1). 


\section{Yosemite Creek Granodiorite}

The Yosemite Creek Granodiorite intrudes the Taft Granite as sheets and irregularly shaped masses in the study area. Three texturally and compositionally distinct units have been observed, and five subunits were delineated directly to the south (Johnson, 2013).

The Yosemite Creek unit in the southern portion of the study area is a mediumgrained granodiorite that intrudes the Taft Granite and Tuolumne Peak granodiorite as a series of elongate bodies and small, sheet-like offshoots. All contacts are sharp and blocks of the Tuolumne Peak granodiorite are incorporated into the Yosemite Creek Granodiorite. Enclaves, schlieren and, mafic bodies are absent. The geometry of the Yosemite Creek bodies strongly suggests amalgamation by small magmatic increments. There is thus little evidence to support the formation of a long-lived magma chamber in this part of the study area.

Several tonalitic to dioritic bodies disaggregate into enclave swarms and dispersed enclaves in the porphyritic subunit of the Yosemite Creek Granodiorite. These features suggest co-magmatism between the granodioritic and the mafic material, but at one location, the granodiorite appears to intrude a mafic body. This relationship may represent late-crystallizing granodiorite reintruding the mafic material, which had already begun to crystallize, providing a stronger rheological contrast than is seen elsewhere.

Internal contacts are not observed in the Yosemite Creek Granodiorite, other than those with the mafic bodies. Enclaves and schlieren are absent in the granodiorite away from mafic bodies. Although the dispersal of enclaves adjacent to mafic bodies points 
towards a mobile system, the heterogeneity of the unit suggests that a large magma chamber did not develop. Field relationships thus indicate construction of the granodiorite by multiple increments, which gave rise to a texturally and compositionally varied pluton in which a short-lived magma chamber, or several small chambers, may have formed, allowing for some mingling or mixing to occur.

\section{Emplacement of Plutonic Rocks}

One of the challenges in attempting to understand magmatic systems is that the magnitude of host rock material transfer documented by field relations is typically minor relative to the amount of magma emplaced. A number of models have been proposed to explain how host rock accommodates magma intruded into the crust. These include stoping, assimilation, ductile flow of host rock, roof uplift, floor depression, magmatic wedging, and tectonically controlled emplacement (e.g., Hutton, 1982; Paterson and Vernon, 1995; Cruden, 1998; Zak and Paterson, 2005; Saint Blanquat et al., 2011). It is likely that in most cases, including within the study area, a combination of processes, operating at various rates and over differing timescales, worked in symphony to accommodate magma as it intruded the crust. It should be noted that in the central Sierra Nevada batholith, direct evidence for material transfer processes is typically lacking (e.g., McFarlan, 2007; Petsche, 2008; Johnson, 2013). 


\section{Stoping and Assimilation}

Stoping operates as an important material transfer process during emplacement of many plutons (Paterson and Vernon, 1995; McNulty et al., 1996; Clarke et al., 1998), but its volumetric significance has been questioned (Glazner and Bartley, 2006). Stoping has been invoked as a significant material transfer process in other plutons of the Sierra Nevada batholith, such as the Tuolumne Intrusive Suite (Zak and Paterson, 2005), but appears to play a more limited role in the emplacement of the plutonic units in the study area, as discussed below.

The best evidence for stoping in the study area is in the Mt. Hoffman granodiorite. Dozens of metasedimentary xenoliths, ranging in length from several centimeters to several meters, were observed. Xenoliths are concentrated along the contact with the map-scale metasedimentary bodies (Plate 1). Rotation is implied by the variation in foliation orientation between the larger host rock bodies and xenoliths. Sharp, stepped, vertical contacts between the Mt. Hoffman granodiorite and metasedimentary bodies are also compatible with stoping (e.g., Zak and Paterson, 2005). Mafic bodies that intruded the Mt. Hoffman granodiorite, likely during late-stage crystallization, incorporate angular, rotated blocks of the granodiorite. The size and abundance of xenoliths indicates that stoping facilitated emplacement of these bodies.

No evidence for stoping was observed where the Taft Granite intrudes the Mt. Hoffman granodiorite. The large body of Mt. Hoffman granodiorite $\sim 1 \mathrm{~km}$ west of the main Taft-Mt. Hoffman contact may be a stoped block, but rotation of foliation is not evident between the block and the main body of Mt. Hoffman granodiorite. 
Alternatively, this body may represent an isolated remnant of the roof of the Taft Granite. Significant exposures of the granodiorite occur at higher elevations within the field area, however, making this interpretation unlikely.

Volumetrically significant blocks of Taft Granite are enclosed by the mafic body west of the Mt. Hoffman granodiorite-Taft Granite contact (see chapter on ROCK DESCRIPTION), and provide evidence for disaggregation by stoping and assimilation of the granite (Fig. 8). Xenoliths of the granite, ranging in size from several millimeters to ten centimeters, are incorporated into the mafic body and several appear to have been broken apart by the intruding magma. This relationship suggests that disaggregation and/or assimilation of stoped blocks may obscure evidence for stoping. Overall, stoping in the Taft Granite appears to be limited to these volumetrically minor mafic bodies.

The Tuolumne Peak granodiorite and Yosemite Creek Granodiorite show evidence for at least minor stoping, as both incorporate angular blocks of older plutons. Contacts between the Tuolumne Peak granodiorite and Taft Granite are sharp and several $2 \times 3 \mathrm{~m}$, angular blocks of the granite are incorporated in the granodiorite. The Yosemite Creek Granodiorite contains several angular blocks of the Tuolumne Peak granodiorite. No xenoliths were observed in the western body of the Yosemite Creek Granodiorite.

\section{Ductile Flow}

Ductile flow of wall rock has been invoked as an important material transfer process to accommodate magma in parts of the Sierra Nevada batholith (Paterson and Vernon, 1995; McNulty et al., 2000; Zak and Paterson, 2005). However, a structural 
aureole is typically absent suggesting that if ductile flow did occur, stoping led to subsequent removal of this record of strain.

In the study area, the margin-parallel foliation seen in several locations in the McGee Lake pendant may define a structural aureole of the Mt. Hoffman granodiorite (Fig. 14). Evaluation is complicated by proximity of metasedimentary rocks to the Tuolumne Intrusive Suite, which may have developed its own structural aureole. There is little evidence that stoping by either intrusion removed and incorporated blocks of metasedimentary rocks, and with them, evidence for ductile flow, as metasedimentary xenoliths are rarely seen. Furthermore, fabric intensity in the xenoliths is similar to that of the pendant. A few ductile shear zones were measured adjacent to tonalitic bodies in the Mt. Hoffman granodiorite, and may record minor ductile flow during intrusion of tonalitic magma. Overall, evidence for ductile flow is weak, and if this process did play a role in emplacement, it was likely minor.

\section{Roof Uplift/Floor Depression}

Material transfer processes during emplacement have long been known to vary with depth. Roof uplift and floor depression are two end members in a continuum of processes that are depth dependent (e.g., Cruden, 1998).

Plutonic rocks in the study area were emplaced at a depth of $\sim 4-11 \mathrm{~km}$ (Ague and Brimhall, 1988), corresponding to pressures of $~ 1-3 \mathrm{~kb}$. The higher values of pressure would likely hinder roof uplift. The absence of pluton roofs precludes observing structures commonly associated with roof uplift, such as draping of stratigraphy over the 
intrusion (e.g., Cruden, 1998). The exception to this may be the remnant of Mount Hoffman granodiorite enclosed within the Taft Granite, which may represent part of the roof of the granite. However, the limited exposure prevents a definitive interpretation. Evidence for piston-like roof uplift, such as brittle faults along intrusion margins, is also absent in the study area. Thus, this style of roof uplift is unlikely, and draping cannot be tested in the study area, a conclusion also reached in areas directly to the south (Johnson, 2013).

Sinking or depression of the pluton floor is considered a viable mechanism for pluton emplacement, particularly in the lower to mid-crust. Sinking of the host rock is accommodated by vertical and lateral ductile flow, an exchange process where host rock sinks as magma moves up to shallower levels (Cruden, 1998). Evidence for floor depression includes ductile flow along pluton walls or sagging of the pluton floor (Cruden, 1998). Although this mechanism is plausible, direct evidence for it is lacking at the current level of exposure, as evidence for ductile flow is limited and the floors of the plutons are not exposed at current crustal levels.

\section{Magmatic Wedging}

Preexisting anisotropies in host rock, such as foliation or older magmatic sheets, may serve as weaknesses and facilitate intrusion of magma. As tabular bodies of magma intrude along planes of weakness host rock is wedged aside, resulting in solidified sheets separating rafts of host rock (Hutton, 1982; Miller and Paterson, 2001; Zak and Paterson, 2005). 
In the study area, plutonic rocks rarely penetrate metasedimentary host rock. Where plutonic rocks intrude older intrusions, as with the sheet-like bodies of the Tuolumne Peak and Yosemite Creek granodiorites, contacts of the younger bodies are not parallel to host rock foliation suggesting that magmatic wedging was not a significant process.

\section{Tectonically Controlled Emplacement}

The concept of tectonic processes accommodating magma involves a "one-toone” crustal transfer whereby tectonic rates equal emplacement rates. In general, however, tectonic and magmatic processes operate on timescales that differ by up to several orders of magnitude (Paterson and Tobisch, 1992; Saint Blanquat et al., 2011). Therefore, for plutons constructed over time periods of more than one million years regional tectonic processes may act as an important material transfer process.

In the study area, evidence for tectonically-controlled emplacement is tenuous at best, as large-scale faults and shear zones are absent. Several shear zones (Cascade Lake shear zone, Bench Canyon shear zone, and Quartz Mountain shear zone) south and east of the study area (Fig. 1) were dominantly active after emplacement of the Yosemite Valley Intrusive Suite (McNulty, 1995; Tobisch et al., 1995; Tikoff and Greene, 1997). Fabrics adjacent to the Bench Canyon shear zone, 15 southeast of the study area, record a period of extensional deformation at $101($ ?)-95 Ma (McNulty, 1995). This shear zone projects towards the study area, but has been obscured by intrusion of the Tuolumne Intrusive Suite. The Bench Canyon shear zone is younger than the Mt. Hoffman granodiorite and therefore did not aid in emplacement of this unit, but this does not 
totally preclude the possibility that extension along the Bench Canyon shear zone facilitated emplacement of younger plutons (i.e. Yosemite Creek Granodiorite and Tuolumne Peak granodiorite) in the study area. Likewise, the Mount Hoffman shear zone, which deforms rocks immediately to the south (Fig. 1), may also have influenced emplacement of plutons in the study area, but was presumably cut out by intrusion of the Taft Granite.

\section{Origin of Magmatic Foliation Orientation}

Magmatic foliation is present in all plutonic units in the study area and is variably defined by aligned, early-formed tabular minerals. These minerals include hornblende, plagioclase, and particularly biotite. Several foliation patterns emerge and are attributed to regional and local strain fields.

\section{Mt. Hoffman Granodiorite}

Magmatic foliation is highly variable in orientation across the study area and is generally at an angle to contacts, but several domains display consistent patterns (Fig. 14). This variation suggests that magmatic foliation in the study area records strain from several sources. Perhaps the most notable pattern is the northwest-striking, steeply dipping fabric in the southern and eastern parts of the Mt. Hoffman granodiorite. Strike is at a high angle to contacts with the metasedimentary host rocks implying that foliation orientation is not related to emplacement. Northwest-striking, steeply dipping foliation 
has also been measured in >98 Ma plutons adjacent to the study area and has been attributed to regional strain. It is therefore likely that this fabric records northeastsouthwest regional shortening strain, potentially from northeast-southwest plate convergence (Zak and Paterson, 2005).

An intriguing foliation pattern occurs in the central and northern parts of the Mt. Hoffman granodiorite (Fig. 14) where foliation strike changes from the center of the Mt. Hoffman granodiorite to the northern contact with the Tuolumne Intrusive Suite. Foliation in the interior of the granodiorite strikes northwest, as to the south, but rotates to an east-west trend to the north. Farther north, within $\sim 0.5 \mathrm{~km}$ of the contact with the Tuolumne Intrusive Suite, foliation abruptly changes to an overall north-south strike. In several areas, in the outer few meters of the pluton, foliation bends into parallelism with the contact. These patterns may be attributable to 1) regional strain, or more specifically to a change in the regional strain field, 2) near-field strain associated with magmatic processes, or 3) a combination of regional strain and near-field processes.

The rotation of fabrics from a northwest to east-west strike may reflect a change in regional strain if crystallization duration or ages of the granodiorite vary from the south to north. Regionally there is no evidence for this change in rocks of this age in the central Sierra Nevada batholith suggesting that variations in foliation strike are likely associated with local processes. Likewise, the abrupt change from an east-west to northsouth striking fabric in the northeast corner of the study area probably represents the interaction between regional strain and local magmatic processes (e.g., margin-parallel flow). 
The presence of metasedimentary bodies along long segments of the eastern and southern margin of the Yosemite Valley Intrusive Suite provides strong evidence that this was the original extent of the Mt. Hoffman granodiorite and Taft Granite. Furthermore, mafic sheets, arguably associated with the Glen Aulin Tonalite, intrude concordantly along the northern contact of the Mt. Hoffman granodiorite and have a generally eastwest strike. This concordance is compatible with the mafic bodies having intruded along anisotropies created by the metasedimentary rock-Mt. Hoffman granodiorite contact. Foliation strike in the Mt. Hoffman granodiorite is thus at a high angle to the original contact, and is attributed to dominantly record regional strain. Areas exhibiting a myriad of fabric orientation may have been more strongly affected by magmatic processes and potentially delineate a distinct magma pulse.

Northeast-striking structures, including magmatic foliation and ductile shear zones, are widespread in all units directly south of the study area and were interpreted by Johnson (2013) to record a previously undocumented component of northwest-southeast shortening. The northeast-striking structures are much less developed in the study area. If northeast-striking foliation in the Mt. Hoffman granodiorite records regional shortening to the south, then the scarcity of foliation with this orientation only $4 \mathrm{~km}$ to the northeast in the study area is problematic. This relationship suggests that the foliation to the south resulted from a more localized stress field than preciously inferred, or reflects strain refraction by the northeast strike of contacts. 


\section{Taft Granite}

Magmatic foliation in the Taft Granite is highly variable in orientation. Rare northwest-striking foliation measured in the field area is at a high angle to host rock contacts and may record regional strain. Other foliation has a generally east-west strike, discordant to the nearby north-south trending contact with the Mt. Hoffman granodiorite and to the overall regional structural grain. This variation in foliation strike is attributed to internal magmatic processes. Additionally, the homogeneity of the Taft Granite is inferred to reflect the development of a sizable magma chamber where convective flow may have produced a complex strain field. In short, both regional strain and internal magma chamber processes are probably recorded by the weak foliation in the Taft Granite.

\section{Yosemite Creek and Tuolumne Peak Granodiorite}

Northeast-striking, steeply dipping foliation is well-developed in the western body of Yosemite Creek Granodiorite and is moderately developed in the Tuolumne Peak granodiorite, the youngest units in the study area. As mentioned above, northeaststriking foliation has been documented in rocks to the south of the study area and foliation of this orientation presumably has the same origin in both areas (see discussion of Mt. Hoffman granodiorite foliation). 


\section{Development of Shear Zones}

Scattered ( 25 observed), 0.1- to 1-m-wide, ductile shear zones are dominantly confined to the eastern half of the study area in the Mt. Hoffman granodiorite and Taft Granite. Most shear zones dip moderately to steeply and strike variably (see section on Ductile Shear Zones in STRUCTURE) (Fig. 16). Well-defined S-C fabrics and $\sigma$-type porphyroclasts indicate reverse sense-of-shear. Reverse shear zones have also been reported in plutons of similar age within the central Sierra Nevada batholith (Tobisch et al., 1995; Mahan et al., 2003; Johnson, 2013). The shear zones are interpreted to have formed after crystallization of the plutons, but before intrusion of the Tuolumne Intrusive Suite. Microstructures indicate recrystallization occurred at moderate to high temperatures (see chapter on Ductile Shear Zones in STRUCTURE).

The majority of shear zones in the study area occur near contacts between plutonic units, internal contacts with mafic bodies, and adjacent to xenoliths and aplitic dikes. Shear zones are therefore interpreted to record regional strain localized by zones with marked rheological contrasts.

The Mt. Hoffman shear zone is a 2-km-wide ductile shear zone that extends for $\sim 6 \mathrm{~km}$ in the Mt. Hoffman granodiorite, lies to the south of the study area, and projects towards the study area (Fig. 1) (Johnson, 2013). However, it is absent in the study area presumably because it was cut out by intrusion of the Taft Granite, as seen to the south. There are several narrow, map-scale bodies of Mt Hoffman granodiorite enclosed in the 
Taft Granite roughly along strike with the shear zone; these bodies contain only a few discontinuous shear zones.

\section{CONCLUSIONS}

1) The Mt. Hoffman granodiorite is a heterogeneous unit displaying textural and compositional variation both inside and outside of the study area. Subunits within the granodiorite, as well as ubiquitous schlieren and mafic bodies, suggest a complex petrologic evolution.

2) The Taft Granite is a voluminous, largely homogenous unit that displays minimal variation in the study area, in contrast to the Taft Granite in Yosemite Valley.

3) Magmatic foliation observed within the study area records both regional strain associated with northeast-southwest shortening and internal magmatic processes.

4) The contact between the Yosemite Valley Intrusive Suite and Tuolumne Intrusive Suite along the salient in the field area has been interpreted to represent the original extent of the Yosemite Valley rocks and likely controlled emplacement of the Tuolumne magmas.

5) Emplacement of plutons in the study area was probably facilitated by several processes, including stoping and minor ductile flow. Other processes, such as floor depression and tectonically controlled emplacement can’t be ruled out. Direct evidence for all of these processes is minimal and does not account for a significant portion of the space required for emplacement of the plutons. A 
similar conclusion has been reached for many plutons in the central Sierran batholith.

6) Evidence compatible with large, internally mobile magma chambers exists within the Mt. Hoffman granodiorite and Taft Granite, but this interpretation requires further testing, particularly with high-resolution geochronological and geochemical studies. The Tuolumne Peak granodiorite and Yosemite Creek Granodiorite both preserve evidence for construction via small increments, probably as narrow sheets. 


\section{REFERENCES CITED}

Ague, J.J., and Brimhall, G.H., 1988, Regional variations in bulk chemistry, mineralogy, and the compositions of mafic and accessory minerals in the batholiths of California: Geological Society of America Bulletin, v. 100, p. 891-911.

Barriere, M., 1977, Deformation associated with the Ploumanac'h intrusive complex, Brittany: Geological Society of London Journal, v. 134, p. 311-324.

Bateman, P.C., 1992, Plutonism in the central part of the Sierra Nevada batholith, California: United States Geological Survey Professional Paper 1483, 186 p.

Bateman, P.C., and Chappell, B.W., 1979, Crystallization, fractionation and solidification of the Tuolumne Intrusive Series, Yosemite National Park, California: Geological Society of America Bulletin, v. 90, p. 465-482.

Bateman, P.C., Kistler, R.W., Peck, D.L., and Busacca, A.J., 1983, Geologic map of the Tuolumne Meadows quadrangle, Yosemite National Park, California: U.S. Geological Survey Map GQ-1570, scale 1:62,500.

Burgess, S.D., Bowring, S.A., Petsche, J., Miller, R.B., and Miller, J.S., 2009, High precision U-Pb CA-TIMS geochronology for the Sentinel and Yosemite Creek granodiorites, Sierra Nevada batholith, CA: A history of punctuated intrusion and protracted crystallization: EOS (Transactions, American Geophysical Union), v. 52, p. 90.

Clarke, D.B., Henry, A.S., and White, M.A., 1998, Exploding xenoliths and the absence of 'elephants' graveyards' in granite batholiths: Journal of Structural Geology, v. 20, p. 1325-1343.

Coleman, D.S., Gray, W., and Glazner, A.F., 2004, Rethinking the emplacement and evolution of zoned plutons: Geochronologic evidence for incremental assembly of the Tuolumne Intrusive Suite, California: Geology, v. 32, p. 433-436.

Cruden, A., 1998, On the emplacement of tabular granites: Journal of Geological Society, London, v. 55, p. 853-856.

Glazner, A.F., 2007, Thermal limitations on incorporation of wall rock into magma: Geology, v. 30, p. 319-322. 
Glazner, A.F., and Bartley, J.M., 2006, Is stoping a volumetrically significant emplacement process?: Geological Society of America Bulletin, v. 118, p. 11851195.

Glazner, A.F., Bartley, J.M., Coleman, D.S., Gray, W., and Taylor, R.Z., 2004, Are plutons assembled over millions of years by amalgamation from small magma chambers?: GSA Today, v. 14, no. 4/5, p. 4-10.

Grasse, S.W., Gehrels, G.E., Lahren, M.M., Schweickert, R.S., and Barth, A.P., 2001, U$\mathrm{Pb}$ geochronology of detrital zircons from the Snow Lake pendant, central Nevada - Implications for Late Jurassic-Early Cretaceous dextral strike-slip faulting: Geology, v. 29, p. 307-310.

Hirth, G., and Tullis, J., 1992, Dislocation creep regimes in quartz aggregates: Journal of Structural Geology, v. 14, p. 145-160.

Huber, N.K., Bateman, P.C., and Wahrhaftig, C., 1989, Geologic map of Yosemite National Park and vicinity: U.S. Geological Survey Map I-1874, scale 1:125,000.

Hutton, D.H.W., 1982, A tectonic model for the emplacement of the Main Donegal Granite, NW Ireland: Journal of the Geological Society of London, v. 139, p. 615631.

Johnson, B., 2013, Structure, construction, and emplacement of Cretaceous plutons in central Sierra Nevada batholith [M.S. thesis]: San Jose, California, San Jose State University, 95 p.

Kistler, R.W., 1973, Geologic map of the Hetch Hetchy Reservoir Quadrangle, Yosemite National Park, California: U.S. Geological Survey Map GQ-1112, scale 1:62,500.

Kruhl, J.H., 1996, Prism- and basal-plane parallel subgrain boundaries in quartz: A microstructural geothermobarometer: Journal of Metamorphic Geology, v. 14, p. 581-589.

Lahren, M.M., and Schweickert, R.A., 1989, Proterozoic and Lower Cambrian miogeoclinal rocks of Snow Lake pendant, Yosemite-Emigrant Wilderness, Sierra Nevada, California: Evidence for major Early Cretaceous dextral translation: Geology, v. 17, p. 156-160.

Mahan, K.H., Bartley, J.M., Coleman, D.S., Glazner, A.F., and Carl, B.S., 2003, Sheeted intrusion of the synkinematic McDoogle pluton, Sierra Nevada, California: Geological Society of America Bulletin, v. 115, p. 1570-1582. 
Matzel, J.E.P., Mundil, R., Paterson, S.R., Renne, P., and Nomade, S., 2005, Evaluating pluton growth models using high resolution geochronology: Tuolumne Intrusive Suite, Sierra Nevada, CA: Geological Society of America Abstracts with Programs, v. 37, no. 7, p. 131.

Matzel, J.E.P., Bowring, S.A., and Miller, R.B., 2006, Time scales of pluton construction at differing crustal levels: Examples from the Mount Stuart and Tenpeak intrusions, North Cascades, Washington: Geological Society of America Bulletin, v. 118, p. 1412-1430.

McFarlan, R., 2007, Structure and emplacement of Buena Vista Crest Intrusive Suite, California [M.S. thesis]: San Jose, California, San Jose State University, 81 p.

McNulty, B.A., 1995, Shear zone development during magmatic arc construction: The Bench Canyon shear zone, central Sierra Nevada, California: Geological Society of America Bulletin, v. 107, p. 1094-1107.

McNulty, B.A., Tong, W., and Tobisch, O.T., 1996, Assembly of a dike-fed magma chamber: The Jackass Lakes pluton, central Sierra Nevada, CA: Geological Society of America Bulletin, v. 108, p. 926-940.

McNulty, B.A., Tobisch, O.T., Cruden, A.R., and Gilder, S., 2000, Multistage emplacement of the Mount Givens pluton, central Sierra Nevada batholith, California: Geological Society of America Bulletin, v. 112, p. 119-135.

Memeti, V., Gehrels, G.E., Paterson, S.R., Thompson, J.M., Mueller, R.M., and Pignotta, G.S., 2010a, Evaluating the Mojave-Snow Lake fault hypothesis and origins of central Sierran metasedimentary pendant strata using detrital zircon provenance analyses: Lithosphere, v. 2, p. 341-360.

Memeti, V., Paterson, S.R., Matzel, J.E.P., Mundil., R., and Okaya, D., 2010b, Magmatic lobes as "snapshots" of magma chamber growth and evolution in large, composite batholiths: An example from the Tuolumne intrusion, Sierra Nevada, California: Geological Society of America Bulletin, v. 122, p. 1912-1931.

Miller, R.B., and Paterson, S.R., 2001, Construction of mid-crustal sheeted plutons: Examples from the North Cascades, Washington: Geological Society of America Bulletin, v. 113, p. 1423-1442.

Miller, C.F., Furbish, D.J., Walker, B.A., Claiborne, L.L., Koteas, G.C., Bleick, H.A., and Miller, J.S., 2011, Growth of plutons by incremental emplacement of sheets in crystal-rich host: Evidence from Miocene intrusions of the Colorado River region, Nevada, USA: Tectonophysics, v. 500, p. 65-77. 
Paterson, S.R., and Tobisch, O.T., 1992, Rates of processes in magmatic arcs: implications for the timing and nature of pluton emplacement and wall rock deformation: Journal of Structural Geology, v. 14, p. 291-300.

Paterson, S.R., and Vernon, R.H., 1995, Bursting the bubble of ballooning plutons: a return to nested diapirs emplaced by multiple processes: Geological Society of America Bulletin, v. 107, p. 1356-1380.

Paterson, S.R., Fowler, T.K., Schmidt, K.L., Yoshinobu, A.S., Yuan E.S., and Miller, R.B., 1998, Interpreting magmatic fabrics in plutons: Lithos, v. 44, p. 53-82.

Paterson, S.R., Okaya, D., Memeti, V., Economos, R., and Miller, R.B., 2011, Magma addition and flux calculations of incrementally constructed magma chambers in continental margin arcs: Combined field, geochronologic, and thermal modeling studies: Geosphere, v. 7, p. 1439-1468.

Petsche, J., 2008, Structure of the Sentinel Granodiorite, Yosemite National Park, California [M.S. thesis]: San Jose, California, San Jose State University, 102 p.

Pitcher, W. S., and Berger, A. R., 1972, The geology of Donegal: A study of granite emplacement and unroofing: New York, Wiley, 435 p.

Ratajeski, K., Glazner, A.F., and Miller, B.V., 2001, Geology and geochemistry of mafic to felsic plutonic rocks in the Cretaceous intrusive suite of Yosemite Valley, California: Geological Society of America Bulletin, v. 113, p. 1486-1502.

Saint-Blanquat, M. (de), Horsman, E., Habert, G., Morgan, S., Vanderhaeghe, O., Law, R., and Tikoff, B., 2011, Multiscale magmatic cyclicity, duration of pluton construction, and the paradoxical relationship between tectonism and plutonism in continental arcs: Tectonophysics, v. 500, p. 20-33.

Solgadi, F., and Sawyer, E.W., 2008, Formation of igneous layering in granodiorite by gravity flow: A field, microstructure and geochemical study of the Tuolumne Intrusive Suite at Sawmill Canyon, California: Journal of Petrology, v. 49, p. 2009-2042.

Stern, T.W., Bateman, P.C., Morgan, B.A., Newell, M.F., and Peck, D.L., 1981, Isotopic $\mathrm{U}-\mathrm{Pb}$ ages of zircon from the granitoids of the central Sierra Nevada: U.S. Geological Survey Professional Paper 1185, 17 p.

Taylor, R.Z., 2004, Structure and stratigraphy of the May Lake interpluton screen, Yosemite National Park, California [M.S. thesis]: University of North Carolina at Chapel Hill, 60 p. 
Tikoff, B., and Greene, D., 1997, Stretching lineations in transpressional shear zones, an example from the Sierra Nevada batholith, California: Journal of Structural Geology, v. 19, p. 29-39.

Tobisch, O.T., Saleeby, J.B., Renne, P.R., McNulty, B., and Tong, W., 1995, Variations in deformation fields during development of a large-volume magmatic arc, central Sierra Nevada, California: Geological Society of America Bulletin, v. 107, p. 148166.

Tullis, J., and Yund, R.A., 1985, Dynamic recrystallization of feldspar: A mechanism for ductile shear zone formation: Geology, v. 13, p. 238-241.

Vernon, R.H., 2004, A practical guide to rock microstructure: Cambridge, United Kingdom, Cambridge University Press, 594 p.

Wiebe, R.A. and Collins, W.J. 1998, Depositional features and stratigraphic sections in plutons: implications for the emplacement and crystallization of granitic magmas: Journal of Structural Geology, v. 20, p. 1273-1289.

Zak, J. and Paterson, S.R., 2005, Characteristics of internal contacts in the Tuolumne Batholith, central Sierra Nevada, California (USA): Implications for episodic emplacement and physical processes in a continental arc magma chamber: Geological Society of America Bulletin, v. 117, p. 1242-1255. 